\title{
Hyperhomocysteinemia and Cardiovascular Disease: Is the Adenosinergic System the Missing Link?
}

\author{
Franck Paganelli $1,2,+$, Giovanna Mottola ${ }^{1,3,+} \mathbb{C}$, Julien Fromonot ${ }^{1,3}$, Marion Marlinge ${ }^{1,3}$, Pierre Deharo ${ }^{1,4}$, \\ Régis Guieu $1,3,+(\mathbb{D})$ and Jean Ruf $1, *,+(\mathbb{D}$ \\ 1 C2VN, INSERM, INRAE, Aix-Marseille University, F-13005 Marseille, France; \\ franck.paganelli@ap-hm.fr (F.P.); giovanna.mottola@univ-amu.fr (G.M.); julien.fromonot@univ-amu.fr (J.F.); \\ marion.marlinge@ap-hm.fr (M.M.); pierre.deharo@ap-hm.fr (P.D.); guieu.regis@orange.fr (R.G.) \\ 2 Department of Cardiology, North Hospital, F-13015 Marseille, France \\ 3 Laboratory of Biochemistry, Timone Hospital, F-13005 Marseille, France \\ 4 Department of Cardiology, Timone Hospital, F-13005 Marseille, France \\ * Correspondence: jean.ruf@univ-amu.fr \\ + These authors contributed equally to this work.
}

Citation: Paganelli, F.; Mottola, G.;

Fromonot, J.; Marlinge, M.; Deharo, P.; Guieu, R.; Ruf, J.

Hyperhomocysteinemia and

Cardiovascular Disease: Is the

Adenosinergic System the Missing

Link? Int. J. Mol. Sci. 2021, 22, 1690.

https://doi.org/10.3390/ijms22041690

Academic Editor: Guido Iaccarino

Received: 14 January 2021

Accepted: 4 February 2021

Published: 8 February 202

Publisher's Note: MDPI stays neutral with regard to jurisdictional claims in published maps and institutional affiliations.

Copyright: (c) 2021 by the authors. Licensee MDPI, Basel, Switzerland. This article is an open access article distributed under the terms and conditions of the Creative Commons Attribution (CC BY) license (https:// creativecommons.org/licenses/by/ $4.0 /)$

\begin{abstract}
The influence of hyperhomocysteinemia (HHCy) on cardiovascular disease (CVD) remains unclear. HHCy is associated with inflammation and atherosclerosis, and it is an independent risk factor for CVD, stroke and myocardial infarction. However, homocysteine (HCy)-lowering therapy does not affect the inflammatory state of CVD patients, and it has little influence on cardiovascular risk. The HCy degradation product hydrogen sulfide $\left(\mathrm{H}_{2} \mathrm{~S}\right)$ is a cardioprotector. Previous research proposed a positive role of $\mathrm{H}_{2} \mathrm{~S}$ in the cardiovascular system, and we discuss some recent data suggesting that HHCy worsens CVD by increasing the production of $\mathrm{H}_{2} \mathrm{~S}$, which decreases the expression of adenosine $\mathrm{A}_{2 \mathrm{~A}}$ receptors on the surface of immune and cardiovascular cells to cause inflammation and ischemia, respectively.
\end{abstract}

Keywords: adenosine; adenosine $\mathrm{A}_{2 \mathrm{~A}}$ receptors; cardiovascular disease; hydrogen sulfide; hyperhomocysteinemia

\section{Introduction}

Cardiovascular disease (CVD) includes conditions that affect the heart or blood vessels. The heart is a pump, and blood vessels are conduits for blood and cells that supply oxygen and nutrients to maintain the molecular mechanisms necessary for vascular development and the functioning of different tissues. Each organ has its own capillary network to fulfill its specific functions, and endothelial cells provide the microvasculature of the different organs. These endothelial cells form a vascular wall that controls organ development, homeostasis and tissue regeneration. Pathological processes, such as arteriosclerosis, compromise the integrity and structure of this vascular wall, and arteriosclerosis most often leads to CVD. The initiating events of atherogenesis involve the retention of lipoproteins in the subendothelial space of the arteries and the activation of endothelial cells. Circulating monocytes adhere to activate endothelial cells, enter the vascular wall, and differentiate into tissue macrophages. These macrophages ingest lipoproteins and turn into foam cells. In addition, synthetic vascular smooth muscle cells accumulate in atheromas and secrete extracellular matrix proteins, and smooth muscle cells and collagen are important components of the fibrous cap that covers the atherosclerotic plaque. It is believed that plaques with a reduced ratio of smooth muscle cells to foam cells are vulnerable to rupture, which is the event inducing thrombosis and, therefore, myocardial infarction [1].

CVD is a leading cause of death, but how the multifactorial pathology develops is not clear. The incidence of cardiovascular morbi-mortality from CVD varies according to conventional risk factors [2]. Factors that affect the risk of developing CVD include a 
genetic history (gender, family, or ethnicity) [3] or a poor lifestyle (smoking, alcohol use, lack of activity, or unhealthy diet) [4]. Hypertension is the most common modifiable risk factor in CVD [5]. High blood pressure is often associated with metabolic deregulation, which leads to high blood cholesterol levels that, such as glucose in type 2 diabetes, damage blood vessels and lead to atherosclerosis. The mechanisms that link the regulation of blood pressure and hypercholesterolemia, the mutual interaction between hypertension and hypercholesterolemia and their influence on the development of atherosclerosis are mainly the renin-angiotensin-aldosterone system, oxidative stress, endothelial dysfunction and increased production of endothelin-1 [6]. Hypertension is also associated with metabolic deregulation of the methionine cycle, which leads to hyperhomocysteinemia (HHCy) [7]. Of all the established risk factors associated with the development of hypertension and its complications such as accelerated cardiac atherosclerosis and premature death, $\mathrm{HHCy}$ is probably the most elusive. The aim of this review is to propose a mechanism by which $\mathrm{HHCy}$ causes an increase in $\mathrm{H}_{2} \mathrm{~S}$ levels, which affects the adenosinergic system, ultimately promoting CVD.

\section{HHCy as a Risk Factor in CVD}

Homocysteine ( $\mathrm{HCy})$ is a thiol group-containing amino acid metabolite that is produced in all cells via the methionine cycle. HCy synthesis occurs via the transmethylation of methionine by S-adenosylmethionine synthetase (SAMS) to form SAM from methionine and ATP. Methyltransferase (MT) converts SAM to S-adenosylhomocysteine (SAH), and SAH hydrolase metabolizes SAH into adenosine and HCy [8-10] (Figure 1). HCy is remethylated to methionine and transsulfurated to cysteine. Remethylation of $\mathrm{HCy}$ involves folate/vitamin $B_{12}$-dependent and vitamin $B_{12}$-independent mechanisms. The former step is catalyzed by the vitamin $B_{12}$-dependent enzyme methionine synthase (MS) and uses $N$-5-methyl tetrahydrofolate (THF) as the methyl group donor, and the latter step is catalyzed by betaine-homocysteine S-methyl transferase (BHMT) and uses the methyl group from betaine [11] (Figure 1).

Approximately $5 \sim 10 \%$ of the total daily cellular production of HCy that is not metabolized within the cell is exported to the plasma compartment, where normal HCy levels range from 5 to $15 \mu \mathrm{mol} / \mathrm{L}$, and this baseline value is maintained in healthy human subjects via constant clearance by the kidney [12-14]. Vitamin $\mathrm{B}_{12}$ and folic acid deficiencies may lead to HHCy, which is linked to the development of CVD [15,16]. HHCy is a condition in which the plasma concentration of $\mathrm{HCy}$ is elevated, which occurs as a result of an imbalance between its biosynthesis and catabolism [17]. The definition of HHCy is controversial, but it is generally defined as plasma $\mathrm{HCy} \geq 10 \mu \mathrm{mol} / \mathrm{L}$ [18-20]. However, a slight increase (10-15 $\mu \mathrm{mol} / \mathrm{L})$ in plasma HCy level is associated with morbi-mortality [21], and a higher cut-off ( $\geq 15 \mu \mathrm{mol} / \mathrm{L})$ was also considered to designate HHCy [22,23]. In conclusion, HHCy is categorized into three classes as mild, moderate and severe $\mathrm{HHCy}$ with plasma $\mathrm{HCy}$ levels ranging from 15 to $30 \mu \mathrm{mol} / \mathrm{L}, 31$ to $100 \mu \mathrm{mol} / \mathrm{L}$ and $>100 \mu \mathrm{mol} / \mathrm{L}$, respectively [24].

HCy contributes to the development of CVD via several mechanisms, such as its adverse effects on the vascular endothelium and smooth muscle cells, which lead to alterations in subclinical arterial structure and function. Therefore, HHCy is an independent risk factor for atherosclerosis leading to CVD [16,25-27]. Several studies showed a clear correlation between HCy plasma levels and the severity of atherosclerosis [28] and support an association between elevated HCy levels and increased cardiovascular mortality [29]. HHCy is associated with the etiology of myocardial infarction and stroke, but the mechanisms of HCy promotion of CVD are not clear [30,31]. HCy may promote CVD via mechanisms involving vascular muscle cell proliferation, a decrease in circulating HDL, conversion to HCy-thiolactone and induction of an autoimmune response and thrombogenesis [32-35]. HHCy activates Nuclear Factor-kappa B (NF- $\mathrm{BB}$ ), which regulates the transcription of various genes involved in inflammatory and immune responses to increase pro-inflammatory cytokines and downregulate anti-inflammatory cytokines [36]. HHCy also induces endothelial cell dysfunction by decreasing endothelial antioxidant defense to 
cause oxidative stress and an increase in the intracellular concentration of reactive oxygen species (ROS) [37]. ROS disturb lipoprotein metabolism, which contributes to the growth of atherosclerotic vascular lesions [38]. HCy acts on vessels by controlling the contractility of vascular smooth muscle cells and the permeability of endothelial cells via the inhibition of endothelial nitric oxide synthase, which produces nitric oxide (NO) [39,40]. Increased HCy is also associated with DNA hypomethylation in vascular disease [41] but this complex regulatory mechanism is tissue-specific [42]. To alleviate the intracellular accumulation of $\mathrm{HCy}$ when the remethylation pathway is impaired, endothelial cells export $\mathrm{HCy}$ to the circulation [43]. The mechanism of HCy transport in the vascular endothelium is not well defined, but human aortic endothelial cells bind and import L-HCy via at least four of the known cysteine sodium-dependent transport systems, namely, $\mathrm{X}_{\mathrm{AG}}, \mathrm{L}, \mathrm{ASC}$ and $\mathrm{A}$, and L-homocysteine is imported via the $\mathrm{X}_{\mathrm{AG}}, \mathrm{L}, \mathrm{ASC}$ and $\mathrm{xc}$ systems [44]. The effects of HHCy on CVD may also be due to the increased production of hydrogen sulfide $\left(\mathrm{H}_{2} \mathrm{~S}\right)$.

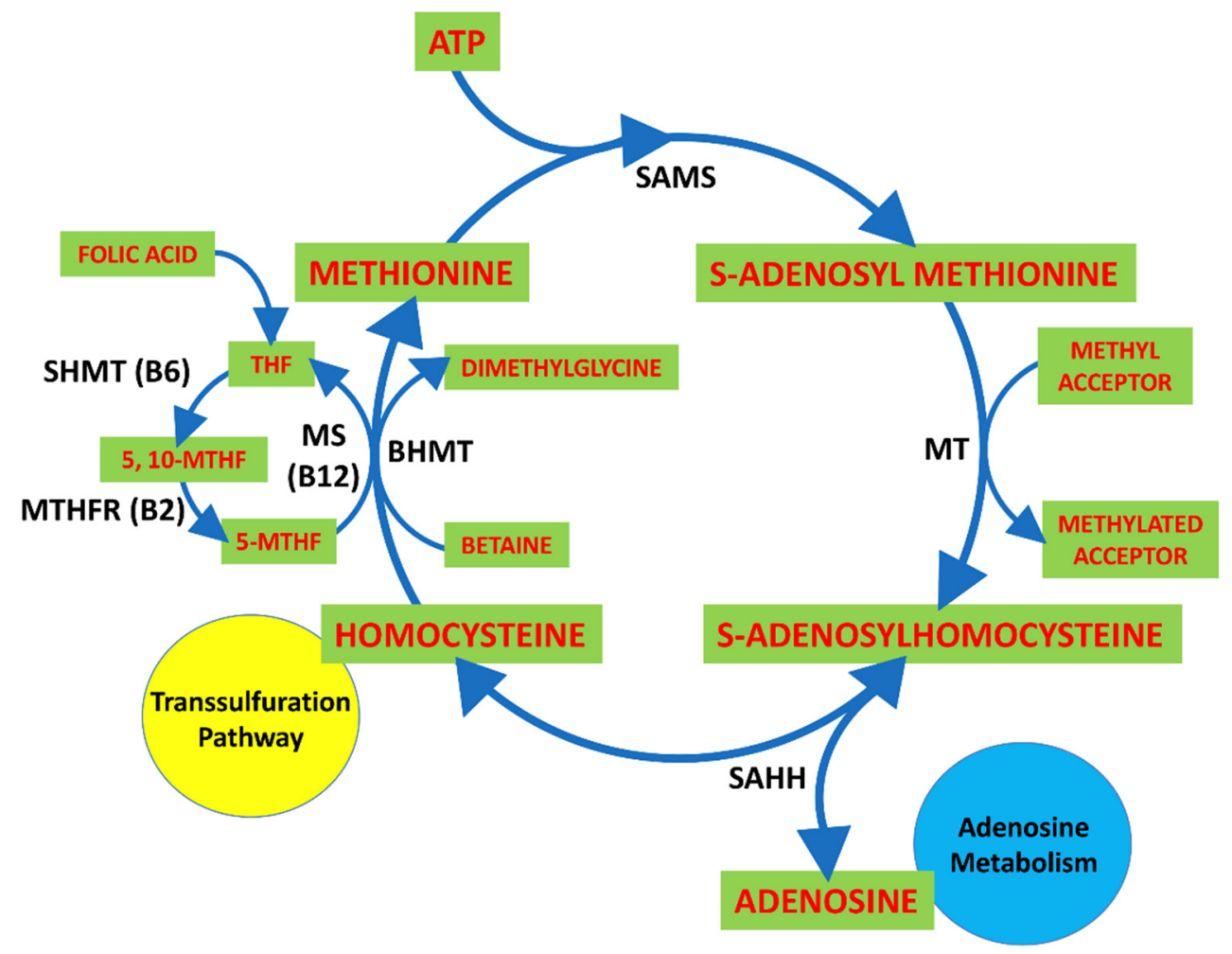

Figure 1. Methionine cycle. Homocysteine (HCy) is biosynthesized from methionine by S- adenosylmethionine synthetase (SAMS), methyltransferase (MT) and S-adenosylhomocysteine hydrolase (SAHH) in sequential steps. Methionine is activated by condensation with adenosine triphosphate (ATP) to yield the ubiquitous methyl donor SAM, which is transformed into S-adenosylhomocysteine (SAH) by donating its methyl group to the substrates of methylation reactions. SAH gives rise to HCy in a reversible reaction that favors SAH over HCy production. SAH is a competitive inhibitor of methylation reactions, and rapid elimination of adenosine and $\mathrm{HCy}$ is required to prevent its accumulation. $\mathrm{HCy}$ may be remethylated to methionine by methionine synthase (MS), which requires folate and vitamin B12, and betaine homocysteine S-methyltransferase (BHMT), which requires betaine, a metabolite of choline. Remethylation of HCy via MS requires 5-methyltetrahydrofolate (5-MTHF), which is derived from 5,10-methylenetetrahydrofolate (5,10-MTHF) in a reaction catalyzed by MTHFR with vitamin B2 as a cofactor. 5-MTHF is converted into tetrahydrofolate (THF) after it donates its methyl group, and THF is converted into 5,10-MTHF by serine hydroxymethyltransferase (SHMT) with vitamin B6 as a cofactor to complete the folate cycle. HCy may enter the transsulfuration pathway, and adenosine can reach its metabolic process. 


\section{3. $\mathrm{H}_{2} \mathrm{~S}$ as a Gasotransmitter}

$\mathrm{H}_{2} \mathrm{~S}$ is the final product of $\mathrm{HCy}$ metabolism. Transsulfuration of HCy is catalyzed via the vitamin $B_{6}$-dependent enzymes cystathionine $\beta$-synthase (CBS) and cystathionine $\gamma$-lyase (CSE). CBS converts HCy and serine into cystathionine, which is used by CSE to generate cysteine [8,9] (Figure 2). CBS and CSE are the major enzymes responsible for the biogenesis of hydrogen sulfide, which is endogenously generated in mammalian tissues $[45,46]$. CBS and CSE catalyze various biochemical mechanisms. CBS produces $\mathrm{H}_{2} \mathrm{~S}$ from cysteine via a $\beta$-elimination reaction, and CSE generates $\mathrm{H}_{2} \mathrm{~S}$ via the $\alpha, \beta$-elimination of cysteine. CBS and CSE perform a $\beta$-replacement reaction, which condenses two cysteine molecules or catalyzes the condensation reaction of $\mathrm{HCy}$ with cysteine via $\beta$ - or $\gamma$-replacement to produce $\mathrm{H}_{2} \mathrm{~S}$. CBS and CSE also affect cysteine $\alpha, \beta$-elimination production of cysteine persulfide to ultimately generate $\mathrm{H}_{2} \mathrm{~S}$ [47] (Figure 2). CBS also produces $\mathrm{H}_{2} \mathrm{~S}$ via $\beta$-replacement in which cysteine is hydrolyzed and condensed with $\mathrm{HCy}$, which provides a biochemical explanation for the $\mathrm{HCy}$-lowering effects of $\mathrm{N}$-acetylcysteine treatments in humans [48]. Under conditions of high HCy levels, the $\alpha, \gamma$-elimination and $\gamma$-replacement reactions likely account for most $\mathrm{H}_{2} \mathrm{~S}$ production by CSE [49] (Figure 2). 3-Mercaptopyruvate (3-MP) sulfurtransferase (MST) in combination with cysteine aminotransferase (CAT) also produces $\mathrm{H}_{2} \mathrm{~S}$ from cysteine [50,51] (Figure 2). L- and D-cysteine may be involved in the biosynthetic pathway for the production of $\mathrm{H}_{2} \mathrm{~S}$ via MST and D-cysteine oxidase. The D-cysteine-dependent pathway acts primarily in the cerebellum and kidney [52]. Cardiovascular cells and tissues are limited in their capacity to metabolize HCy because these cells do not express cystathionine $\beta$-synthase, which is the first enzyme in the transsulfuration pathway $[53,54]$.

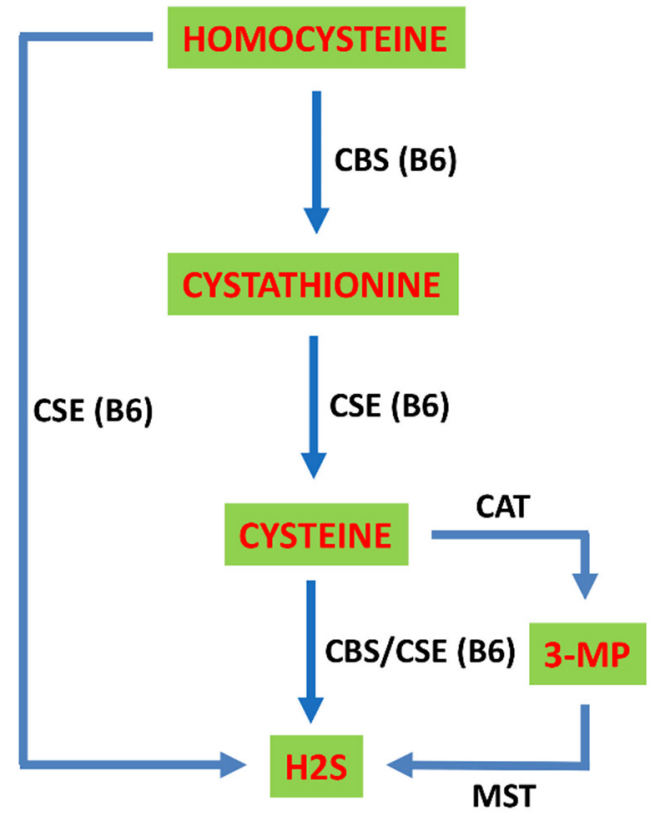

Figure 2. Transsulfuration pathway. HCy may be sequentially converted into cystathionine then cysteine by two vitamin B6-dependent enzymes, cystathionine $\beta$-synthase (CBS) and cystathionine $\gamma$-lyase (CSE), which subsequently results in the generation of $\mathrm{H}_{2} \mathrm{~S}$. $\mathrm{HCy}$ and cysteine are substrates for $\mathrm{H}_{2} \mathrm{~S}$ production by CBS, CSE, cysteine aminotransferase (CAT) and 3-mercaptopyruvate (3-MP) sulfurtransferase (MST).

Genetic disorders in the enzymes responsible for HCy metabolism, such as mutations in N-5,10-methylenetetrahydrofolate reductase (MTHFR) and CBS, may result in moderate or severe HHCy [55]. CBS, CSE and MST are differentially expressed in various systems and affect the functions of these systems via the production of $\mathrm{H}_{2} \mathrm{~S}$. The physiological functions of $\mathrm{H}_{2} \mathrm{~S}$ are mediated via different molecular targets, such as different ion channels 
and signaling proteins [56]. Immunohistochemistry localized CBS in the endothelium of small pial arteries and intracerebral arterioles, capillary walls, neurons and vascular nerves. CSE is localized in smooth muscles and the thoracic aorta, where it is the main enzyme producing $\mathrm{H}_{2} \mathrm{~S}$. MST and CAT are localized in the vascular endothelium of the thoracic aorta $[57,58]$.

$\mathrm{H}_{2} \mathrm{~S}$ is a gasotransmitter known for its regulatory role in many physiological processes [59]. $\mathrm{H}_{2} \mathrm{~S}$ works with $\mathrm{NO}$ and carbon monoxide (CO) as an important endogenous signaling molecule in mammalian cells and tissues [60-64], specifically in the cardiovascular and nervous systems $[65,66]$. One important property of $\mathrm{H}_{2} \mathrm{~S}$ is its biphasic pharmacological mode of action. At low concentrations, $\mathrm{H}_{2} \mathrm{~S}$ exerts modulatory effects and acts as a cytoprotective, antioxidant and anti-inflammatory agent [63,67]. In contrast, higher concentrations of $\mathrm{H}_{2} \mathrm{~S}$ induce deleterious actions, including pro-oxidant effects and cytostatic and cytotoxic responses. These responses involve numerous signal transduction pathways and molecular targets, including $\mathrm{K}_{\text {ATP }}$ channels, Akt, AMP kinase, PTEN, NF- $\mathrm{kB}$, Nrf2, proline-rich kinase 2 , the adenylate cyclase and guanylate cyclase systems and inhibition of cytochrome C oxidase [63,67-69].

\section{1. $\mathrm{H}_{2} \mathrm{~S}$ in Pathophysiological Conditions}

The role of $\mathrm{H}_{2} \mathrm{~S}$ in vascular diseases, inflammation, critical illness, reperfusion injury, various nervous system diseases, metabolic diseases and cancer was extensively reviewed [70-78]. Evidence in support of a role of $\mathrm{H}_{2} \mathrm{~S}$ deficiency in vascular disorders, such as hypertension and atherosclerosis, is accumulating $[79,80]$. Other review articles addressed the vascular biology of $\mathrm{H}_{2} \mathrm{~S}$ and the mechanisms of HHCy-induced vascular injury [81,82]. CSE may be primarily responsible for changes in $\mathrm{H}_{2} \mathrm{~S}$ production in $\mathrm{HHCy}$ [49]. Accumulating evidence supports the inhibitory effect of $\mathrm{HCy}$ on $\mathrm{H}_{2} \mathrm{~S}$ generation [83-85], but there were also reports of elevated $\mathrm{H}_{2} \mathrm{~S}$ levels in HHCy [86,87]. The evidence of defective and enhanced $\mathrm{H}_{2} \mathrm{~S}$ production under HHCy conditions and the metabolic imbalance of $\mathrm{HCy}$ and $\mathrm{H}_{2} \mathrm{~S}$ in cardiovascular pathologies suggests that changes in the $\mathrm{H}_{2} \mathrm{~S} / \mathrm{HCy}$ ratio may be more valuable than changes in the absolute concentrations of $\mathrm{H}_{2} \mathrm{~S}$ and $\mathrm{HCy}$ in depicting the role of these metabolites in disease pathogenesis [88-90]. There are growing controversies on the physiologically significant concentrations of $\mathrm{H}_{2} \mathrm{~S}$ and its biological effects [91,92]. $\mathrm{H}_{2} \mathrm{~S}$ stimulates or inhibits intracellular transduction pathways, cell proliferation, apoptosis and hemostasis [59,93-98]. $\mathrm{H}_{2} \mathrm{~S}$ also exerts pro- and anti-inflammatory effects $[65,99,100]$. Only a few studies showed changes in the levels of $\mathrm{H}_{2} \mathrm{~S}$ in human diseases, and most of these measurements were indirect and measured compounds linked to $\mathrm{H}_{2} \mathrm{~S}$, such as thiosulfate or sulfhemoglobin, rather than $\mathrm{H}_{2} \mathrm{~S}$ itself [101]. Due to its vasorelaxative and vasoprotective properties, $\mathrm{H}_{2} \mathrm{~S}$ may be useful in the treatment of arterial hypertension by decreasing peripheral resistance [92]. Research on the clinical and fundamental aspects of $\mathrm{H}_{2} \mathrm{~S}$ is in full development, particularly the relationship between the production of $\mathrm{H}_{2} \mathrm{~S}$ and epigenetics such as DNA methylation and DNA damage repair [102].

\section{2. $\mathrm{H}_{2} \mathrm{~S}$ in Immune Cells}

The immune cells are in permanent contact with $\mathrm{H}_{2} \mathrm{~S}$ because of the endogenous and exogenous production from the surrounding parenchymal cells, which regulates their viability and function. The downregulation or genetic defect in endogenous $\mathrm{H}_{2} \mathrm{~S}-$ producing enzymes leads to the onset or development of autoimmune diseases [103]. Monocytes/macrophages express CBS, CSE and MST, and CSE and MST are likely the primary enzymes. Pro-inflammatory agents, such as liposaccharide (LPS), tend to upregulate CSE, and anti-inflammatory and cytoprotective agents, such as steroids and statins, inhibit its expression [104-107]. Bacterial LPS increases CSE expression and concomitant $\mathrm{H}_{2} \mathrm{~S}$ production in macrophages via activation of the p38 MAP kinase pathway, and glucocorticoids prevent this upregulation $[104,105,108]$. CSE upregulation in macrophages is also dependent on activation of the NF- $\mathrm{KB}$ and ERK pathways [109]. $\mathrm{H}_{2} \mathrm{~S}$-induced signaling appears 
to play an important role in $\mathrm{T}$ cell activation. Whether $\mathrm{H}_{2} \mathrm{~S}$ is produced by activated $\mathrm{T}$ cells or administered exogenously, it acts as an autocrine or paracrine enhancer of $\mathrm{T}$ cell activation. Administration of $\mathrm{H}_{2} \mathrm{~S}$ at nanomolar concentrations boosts $\mathrm{T}$ cells and upregulates the expression of activation markers, such as CD69, IL-2 and CD25 [110]. The action of $\mathrm{H}_{2} \mathrm{~S}$ protects immune cells from various deleterious effects, such as oxidative stress (ROS production) or inflammatory runaway. The exogenous administration of $\mathrm{H}_{2} \mathrm{~S}$ donors exerted anti-inflammatory effects in various local and systemic inflammatory diseases, such as brain disease, neoplastic disease of the colon, inflammatory disease joints, kidneys, cardiovascular, ophthalmic and dermatological diseases [67,111-123]. Paradoxically, a given $\mathrm{H}_{2} \mathrm{~S}$ donor may have beneficial effects on the immune system but undesirable effects on the vascular system and vice versa. Although $\mathrm{H}_{2} \mathrm{~S}$ acts on various immune cells (macrophages, $\mathrm{T}$ lymphocytes, etc.), it exerts little-known complex effects on the interactions between immune and nonimmune processes. For example, $\mathrm{H}_{2} \mathrm{~S}$ reversed adenosinergic impairment of $\mathrm{T}$ cell viability via suppression of NF- $\mathrm{kB}$, which downregulated $\mathrm{A}_{2 \mathrm{~A}} \mathrm{R}$ expression and may also affect the cardiovascular system [124].

\section{Adenosine as a Purinergic Modulator of Cardiovascular and Immune Systems}

Adenosine is a ubiquitous autacoid that is derived from the dephosphorylation of ATP intracellularly or via the extracellular ectoenzymes CD39 and CD73. Most types of cells release ATP. At the intracellular level, some adenosine also originates from the methionine cycle via the hydrolysis of SAH, which leads to the formation of HCy and adenosine in a stoichiometric ratio. Intra- and extracellular adenosine is deaminated to inosine by adenosine deaminase and joins the end product of the catabolism of purines, uric acid via nucleosidase and xanthine oxidase to yield hypoxanthine and xanthine, respectively $[125,126]$ (Figure 3). Extracellularly, adenosine acts as a signaling molecule by interacting with the integral membrane proteins adenosine receptors or P1 purinergic receptors. Four subtypes were cloned and named: $A_{1}, A_{2 A}, A_{2 B}$ and $A_{3}$ receptors. The intracellular segment of each adenosine receptor subtype interacts with the appropriate heterotrimeric guanine nucleotide-binding protein (G-protein) with subsequent activation of an intracellular signal transduction mechanism. Adenosine receptor subtypes are divided into two main categories: (i) receptors that are coupled to inhibitory G-proteins (Gi), such as adenosine $A_{1} R$ and $A_{3} R$; and (ii) receptors that are coupled to stimulating G-proteins (Gs), like $A_{2 A} R$ and $A_{2 B} R$ [127]. Adenosine receptors are pleiotropic, and other G-protein subtypes $\left(\mathrm{G}_{\mathrm{o}}, \mathrm{G}_{\mathrm{q}}, \mathrm{G}_{\mathrm{olf}}\right)$ are also involved in signal transduction depending on the degree of activation or cellular/subcellular localization [128]. In addition to the exofacial expression of adenosine receptors, adenosine availability and extracellular concentration are also crucial in distinguishing which adenosine receptor subtype is activated. Interstitial adenosine levels increase under conditions of high metabolic demand, such as exercise, and low energy intake, such as ischemia, to reach physiologically relevant concentrations. Adenosine is released into the extracellular space to restore the balance between local energy needs and energy supply [129].

The transfer of adenosine to both sides of the cell is performed via specific proteins, called nucleoside transporters (NTs). NTs alter cellular and plasma adenosine levels $[130,131]$. The transport of adenosine across the cell membrane is crucial because it regulates the levels of extracellular adenosine that come into contact with surface receptors. Two types of NTs were identified: (i) four equilibrative nucleoside transporters (ENT1 to ENT4) [132,133]; and (ii) three concentrative transporters (CNT1 to CNT3) [134]. The increase in ENT and CNT activities may reduce the availability of extracellular adenosine for its receptors, which attenuates their effects. Therefore, NTs act as crucial players in adenosine function by controlling the local levels of adenosine near adenosine receptors. The effectiveness of this transport system is particularly active in humans, and it is responsible for the extremely short half-life of adenosine in human blood. Adenosine, its receptors and nucleoside transporters together form the "adenosinergic system", which exerts fine regulation in multiple physiological and pathophysiological processes [135-137]. 


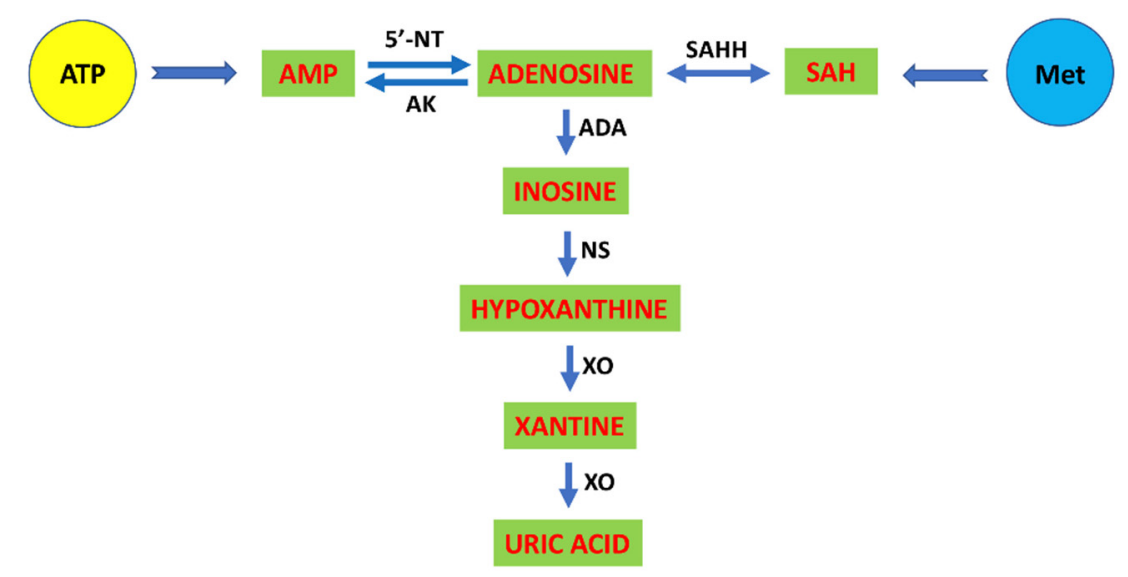

Figure 3. Intracellular adenosine metabolism. Adenosine comes primarily from ATP degradation in the intra- and extracellular environment. In the cytosol, adenosine produced from AMP via $5^{\prime}$-nucleotidase $\left(5^{\prime}\right.$-NT) may be phosphorylated again by adenosine kinase (AK). Some adenosine arises intracellularly from the metabolism of methionine (Met) via the reversible action of S-adenosylhomocysteine hydrolase (SAHH). Intra- and extracellular adenosine is successively degraded into inosine by adenosine deaminase (ADA), into hypoxanthine by nucleosidase (NS) and into xanthine then uric acid by xanthine oxidase $(\mathrm{XO})$.

\subsection{Adenosine Receptors in the Immune System}

Adenosine and its receptors play a role in the modulation of inflammation and the immune response [138]. Adenosine released into extracellular spaces occurs in response to inflammation $[139,140]$. Molecular agents other than adenosine stimulate (agonist) or inhibit (antagonist) its receptors in certain diseases. Coffee consumption is associated with a lower risk of type 2 diabetes. Overall, the experimental and epidemiological evidence elucidated a protective effect of coffee consumption in this disease and showed that caffeine reduced the production of pro-inflammatory cytokines and increased anti-inflammatory processes via the inhibition of $\mathrm{A}_{1} \mathrm{R}, \mathrm{A}_{2 \mathrm{~A}} \mathrm{R}$ and $\mathrm{A}_{2 \mathrm{~B}} \mathrm{R}$ signaling. Caffeine produces biphasic effects. Effects of low doses of caffeine are mediated by adenosine blockade. High dose effects are not due to adenosine antagonism but have a less well known underlying mechanism [141,142]. Coffee consumption seems to have beneficial effects on subclinical inflammation and HDL cholesterol and repeated intake of caffeine paradoxically leads to upregulation of $\mathrm{A}_{2 \mathrm{~A}} \mathrm{R}$ which is accompanied by sensitization to the actions of the agonist HE-NECA $[143,144]$.

Pharmacological activation of $\mathrm{A}_{2 \mathrm{~A}} \mathrm{R}$ using the agonist ATL-146e in diabetic rats ameliorated diabetes-induced histological and functional changes in kidneys and reduced the inflammation associated with diabetic nephropathy [145]. Chronic treatment with the $\mathrm{A}_{2 \mathrm{~A}} \mathrm{R}$ agonist CGS-21680 prevented proteinuria and glomerular damage in diabetic rats via an anti-inflammatory mechanism that was independent of oxidative stress and kidney hypoxia [146]. Adenosine receptors regulate the immune system and act on inflammation and immunes disorders. $\mathrm{A}_{2 \mathrm{~A}} \mathrm{R}$ agonists have anti-inflammatory actions in numerous diseases, including ischemia, arthritis, sepsis, pulmonary and bowel disease and wound healing. Studies in mice and rats demonstrated that the anti-inflammatory effects of methotrexate were lost when animals were treated with $A_{2 A} R$ and $A_{3} R$ antagonists and when these receptors were deleted. Similar effects were observed in patients with rheumatoid arthritis treated with methotrexate who ingested large amounts of caffeine, an adenosine receptor antagonist $[138,147]$. Activation of $\mathrm{A}_{2 \mathrm{~A}} \mathrm{R}$ by endogenous adenosine contributed to the production of interleukin-10 (IL-10) in polymicrobial sepsis [148]. IL10-mediated signaling was significantly attenuated in macrophages derived from $\mathrm{A}_{2 \mathrm{~B}} \mathrm{R}$ knockout mice [149]. Accumulating evidence suggests that chronic silent inflammation is a key feature of abdominal obesity, metabolic syndrome, type 2 diabetes and cardiovascular disease [150-152]. The contribution of inflammation to the disease is supported by the re- 
sults of preclinical studies and new clinical trials using anti-inflammatory approaches [151]. $\mathrm{A}_{3} \mathrm{R}$ has a complex immune-modulatory role and may promote pro- and anti-inflammatory processes. Current knowledge on the role of adenosine $A_{3} R$ in CVD is limited, but studies in knockout mice demonstrated that the absence of $\mathrm{A}_{3} \mathrm{R}$ signaling prevented the development of hypertension and alleviated kidney and cardiovascular damage via various mechanisms, including a reduction in the population of antigen-presenting cells, an increase in immune homeostasis and a decrease in chronic inflammation and oxidative stress during disease [153]. Activation of $\mathrm{A}_{2 \mathrm{~A}} \mathrm{R}$ and $\mathrm{A}_{2 \mathrm{~B}} \mathrm{R}$ via the inhibition of oxidative activity may have strong modulatory effects on the immune system and arrest the progression of adverse effects in various disorders.

Neutrophils express the four types of adenosine receptors [154]. $A_{2 A} R$ has a high affinity for adenosine, and it is expressed on basophils, mast cells, monocytes, dendritic cells, T and B cells and NK cells [155]. Several studies demonstrated that activation of $\mathrm{A}_{2 \mathrm{~A}} \mathrm{R}$ signaling enhanced IL-10 production, inhibited macrophage infiltration, suppressed pro-inflammatory cytokines from $\mathrm{T}$ cells and myeloid cells, and increased regulatory $T$ cell expression [147]. Suppressive effects of the $A_{2 A} R$ on leukocyte function in vitro and in vivo are widely described [156]. $A_{2 A} R$ agonists inhibit human neutrophil activation [157-159] and reduce cytokine production induced by $\mathrm{T}$ cell receptor engagement [160]. $\mathrm{A}_{2 \mathrm{~A}} \mathrm{R}$ agonists inhibit neutrophil adhesion and infiltration, inflammatory cytokine production, neutrophil degranulation and oxidative burst [156]. $\mathrm{A}_{2 \mathrm{~A}} \mathrm{R}$ knockout mice exhibited increased leukocyte migration and poor defense against tissue damage in various models of inflammation, such as lipopolysaccharide-induced lung damage, inflammation by methotrexate and its analog MX-68 and the formation of excisional wounds [161-164]. In mice deficient in $\mathrm{A}_{2 \mathrm{~A}} \mathrm{R}$ and apolipoprotein $\mathrm{E}$, which play crucial roles in the regulation of lipid metabolism and atherogenesis, the absence of $\mathrm{A}_{2 \mathrm{~A}} \mathrm{R}$ improved leukocyte recruitment and increased the size of the arterial neointima in injured carotid arteries [165]. Neutrophil $\mathrm{A}_{2 \mathrm{~A}} \mathrm{R}$ inhibited inflammation in a rat model of meningitis and the oxidative activity of human neutrophils via the AMP/PKA cyclic pathway $[166,167] . \mathrm{A}_{2 \mathrm{~A}} \mathrm{R}$ are negative immune regulators that may be used to manipulate $\mathrm{T}$ cells, particularly during anti-tumor immune responses [168].

\subsection{The Adenosinergic and Cardiovascular Systems}

The adenosinergic system regulates many physiological and pathophysiological states via modification of adenosine production or the tissue expression of different types of receptors $[169,170]$. During myocardial ischemia, most cell types, including myocytes and vascular endothelial cells, release adenosine extracellularly into the blood in response to decreased oxygen levels. The adenosine concentration in the coronary sinus is proportional to the degree of coronary artery stenosis [171]. Elevated adenosine plasma levels are higher in severe CAD than in healthy subjects [172]. Notably, HHCy was also associated with severe CAD [173].

Most of the cells involved in the cardiovascular system express adenosine receptors on their surface [174]. $A_{1} R, A_{2 A} R, A_{2} B$ and $A_{3} R$ were localized in the heart, and their distribution depends on the tissue [175]. For example, high levels of $A_{1} R$, with a high affinity for adenosine, are expressed in the atria, primarily in the right atrium and lower expression was found in ventricular myocytes $[174,176] . \mathrm{A}_{1} \mathrm{R}$ is also expressed in smooth muscles and endothelial coronary tissues [177]. $\mathrm{A}_{2 \mathrm{~A}} \mathrm{R}$ is fully expressed in the cardiovascular system, particularly in the arteries, atria and ventricular tissue $[174,178,179]$.

Adenosine and its receptors strongly affect heart rhythm and blood pressure [169]. $A_{1} R$ and $A_{3} R$ protect the cardiovascular system against ischemia/reperfusion injury by improving mitochondrial function [140]. During spontaneous or induced myocardial ischemia, adenosine acts on coronary blood flow via $A_{2 A} R$ and $A_{2 B} R$. During ischemia, adenosine release from endothelial cells induces $\mathrm{A}_{2 \mathrm{~A}} \mathrm{R}$ activation and cAMP production, which correlate with coronary vasodilation [180]. Myocardial anti-ischemic properties were attributed to $A_{1} R$ and $A_{2 A} R$ because a selective $A_{1} R$ agonist restricted the increase in 
heart rhythm and $A_{2 A} R$ knockout mice suffer from tachycardia and hypertension [181]. In addition to this cardioprotective property, the activation of $\mathrm{A}_{2 \mathrm{~A}} \mathrm{R}$ exerts a pleiotropic action on coronary smooth muscle cells, endothelial cells and mononuclear cells, which leads to vasodilation, neoangiogenesis and decreased levels of pro-inflammatory cytokines (IL-1 $\beta$, IL-6 and TNF- $\alpha$ ) $[127,182] . A_{2 B} R$ is also involved in coronary vasodilation in myocardial ischemia $[183,184]$. Although the activation of $\mathrm{A}_{2 \mathrm{~A}} \mathrm{R}$ and $\mathrm{A}_{2 \mathrm{~B}} \mathrm{R}$ upon exposure to high plasma levels of adenosine results in beneficial effects on the myocardium for a shortterm period, the long-term activation of these receptors during chronic exposure to high adenosine plasma levels is harmful [127]. Primarily $A_{2 A} R$, but also $A_{2 B} R$ despite having the lowest affinity for adenosine, are expressed in ventricular myocytes and fibroblasts and modulate inotropic properties and ventricular function in animals [185,186]. Reported evidence reveals that activation of $\mathrm{A}_{2 \mathrm{~B}} \mathrm{R}$ in smooth muscles of coronary arteries contributes to coronary vasodilation [187]. The myocardial expression of $A_{3} R$ is very low, but it is expressed within the heart and seems to play a role in coronary artery muscle cells and other smooth muscle cells, where these receptors modulate inward potassium channels and cAMP production [188-190].

\subsection{Adenosine and Its Receptors in Coronary Artery Disease (CAD)}

Acute coronary syndrome and its most common consequence, sudden cardiac death, is a major public health problem and accounts for approximately $50 \%$ of all cardiovascular deaths, of which at least $25 \%$ are the first symptomatic cardiac events [191]. Coronary artery stenosis causes a severe imbalance in oxygen supply and demand, which results in ischemia. Reperfusion strategies are the current standard treatment for acute coronary syndrome, but these strategies may lead to paradoxical cardiomyocyte dysfunction, known as ischemic reperfusion injury, and the exact mechanisms are not known (e.g., deep inflammatory response, neurohumoral activation and oxidative stress) [192]. Adenosine exerts numerous effects in the heart, including modulation of the cardiac response to stress, particularly during myocardial ischemia and reperfusion [193]. Adenosine is also a potent autocrine and paracrine immunosuppressive nucleoside that is released in the vicinity of damaged cells in conditions of metabolic stress, such as ischemia, tissue injury or inflammation $[155,194]$. Extracellular adenosine has been referred to as a "safety signal" that dampens hypoxia-induced inflammation during ischemia and reperfusion [195]. Extracellular conversion of ATP to adenosine has a central role in attenuating sterile inflammation during ischemia-reperfusion injury. Experimental studies showed that pharmacological strategies to increase the breakdown of ATP to adenosine were effective in attenuating tissue injury and pathogen-free inflammation during ischemia and reperfusion [196-202]. Several experimental trials provide evidence of a protective role of adenosine signaling in models of ischemia and reperfusion via activation of $\mathrm{A}_{2 \mathrm{~A}} \mathrm{R}$ on inflammatory cells [203-205] or activation of $A_{2 B} R$ on the vascular endothelium, epithelium or cardiac myocytes [200,206-208]. $A_{2 B} R$ signaling controls the expression of the circadian protein Per2, which stabilizes hypoxia-inducible factor (HIF), promotes glycolytic metabolism and has cardioprotective effects. Exposure of mice to intense light stabilized Per2 in the heart and reduced cardiac injury after myocardial ischemia [209]. Activation of $\mathrm{A}_{2 \mathrm{~A}} \mathrm{R}$ on $\mathrm{T}$ cells attenuated ischemia and reperfusion in experimental models of sickle cell disease [204]. $\mathrm{A}_{2 \mathrm{~A}} \mathrm{R}$ reduces inflammation by acting on pro-inflammatory cells to attenuate the release of pro-inflammatory cytokines and decreasing the level of endothelial adhesion molecules. Numerous preclinical studies using $\mathrm{A}_{2 \mathrm{~A}} \mathrm{R}$ agonists and antagonists, $A_{2 A} R$ knockout and chimeric mice showed the therapeutic potential of $A_{2 A} R$ agonists for the treatment of ischemia-reperfusion injury and autoimmune diseases [210].

We showed that patients with CAD had low levels of $A_{2 A} R$ on the surface of peripheral blood mononuclear cells (PBMCs) $[129,172,211]$. PBMCs are a valuable surrogate for cardiovascular cells to study the adenosinergic profile in patients with CAD because the behavior of $A_{2 A} R$ in the two cell types is similar in terms of $A_{2 A} R$ level and cAMP production, which was reported for the left ventricle in cardiac transplant recipients, the 
aorta and coronary artery tissues, and femoral arteries [172,212,213]. The properties of $A_{2 A}$ R expressed by PBMCs mirror the properties of $A_{2 A} R$ in the vascular wall likely because PBMCs are exposed to blood flow and are in contact with all tissues. This correlation of expression and function of $\mathrm{A}_{2 \mathrm{~A}} \mathrm{R}$ in the two compartments is certainly a reflection of systemic regulation. Therefore, it offers a unique opportunity to study the adenosinergic system and its behavior under ischemic conditions in coronary arteries [126].

A recent study correlated a low level of $\mathrm{A}_{2 \mathrm{~A}} \mathrm{R}$ in PBMCs with a high level of plasma cholesterol in patients with familial hypercholesterolemia, which reinforces the link between the immunosuppressive adenosinergic system and chronic inflammation in the atherogenic process [214]. Notably, the final product of adenosine degradation, uric acid, was significantly associated with CAD and endothelial dysfunctions $[215,216]$. The decrease in the level and activity of $\mathrm{A}_{2 \mathrm{~A}} \mathrm{R}$ contributes to the maintenance and worsening of $\mathrm{CAD}$ via modification of the adaptive vasodilation of the coronary arteries when an oxygen supply is necessary, such as during the exercise stress test $[129,136]$.

\section{Adenosinergic System, $\mathrm{HCy}$ and $\mathrm{H}_{2} \mathrm{~S}$ in $\mathrm{CAD}$}

As previously shown, adenosine comes from the methionine cycle, and its production is linked to HCy metabolism. HCy and adenosine are independently associated with cardiovascular disorders. Recent data suggest a link between HCy and adenosine, which may explain the higher cardiovascular risk observed in HHCy. For example, hypoxia increased intracellular adenosine production from ATP to form SAH with HCy via SAH hydrolase. HCy enters the cell through transporters, and it is no longer the limiting substrate for the production, along with adenosine, of SAH by reversing the reaction of SAH hydrolase. The resulting high concentration of SAH forces the enzyme to return, as in basal conditions, to the production of adenosine and $\mathrm{HCy}$, which accumulate in the cell and are catabolized to uric acid and $\mathrm{H}_{2} \mathrm{~S}$, respectively [217]. Notably, HCy plasma levels in CAD patients correlated with adenosine and uric acid plasma levels and a decrease in $A_{2 A} R$ production and function $[218,219]$. Alternately, adenosine induced a time- and dose-dependent increase in $\mathrm{HCy}$ in hepatoma cultured cells [218]. $\mathrm{H}_{2} \mathrm{~S}$ also decreased the level of $\mathrm{A}_{2 \mathrm{~A}} \mathrm{R}$ expression in lymphocytes, which led to adenosinergic immunosuppression and the promotion of inflammation against a background of elevated HCy [217]. The downregulation of $\mathrm{A}_{2 \mathrm{~A}} \mathrm{R}$ due to the increase of $\mathrm{HCy}$ in the blood may be explained by a decrease in the level of $\mathrm{A}_{2 \mathrm{~A}} \mathrm{R}$ in the PBMCs, which was found concomitant with their accumulation in extracellular vesicles isolated from the plasma of CAD patients with HHCy [220]. $A_{2 A} R$ is the major adenosine receptor expressed in platelets and mediates the inhibition of platelet aggregation [221]. A decrease in the expression of $\mathrm{A}_{2 \mathrm{~A}} \mathrm{R}$ on platelets due to $\mathrm{HHCy}$ via $\mathrm{H}_{2} \mathrm{~S}$ could promote their aggregation. Consistently, $\mathrm{HHCy}$ in patients was associated with increased platelet aggregation via the $\mathrm{H}_{2} \mathrm{~S}$ pathway, which contributed to atherothrombosis, stroke and myocardial infarction [86]. Therefore, we propose that $\mathrm{HHCy}$, via the elevated production of $\mathrm{H}_{2} \mathrm{~S}$, damages the cardiovascular system by reducing the number of $\mathrm{A}_{2 \mathrm{~A}} \mathrm{R}$ expressed on cardiac myocytes, and endothelial and immune cells under ischemia-hypoxia (Figure 4). By neutralizing vasodilation and the adenosinergic immune suppression via the action of $\mathrm{H}_{2} \mathrm{~S}$ on NF- $\mathrm{kB}$ and HIF, HHCy may decrease blood flow and exacerbate $\mathrm{T}$ cell infiltration and the concomitant release of pro-inflammatory cytokines in cardiovascular tissue. Therefore, the increased risk of coronary heart disease associated with HHCy may be the consequence of elevated levels of $\mathrm{H}_{2} \mathrm{~S}$ on the adenosinergic system. 


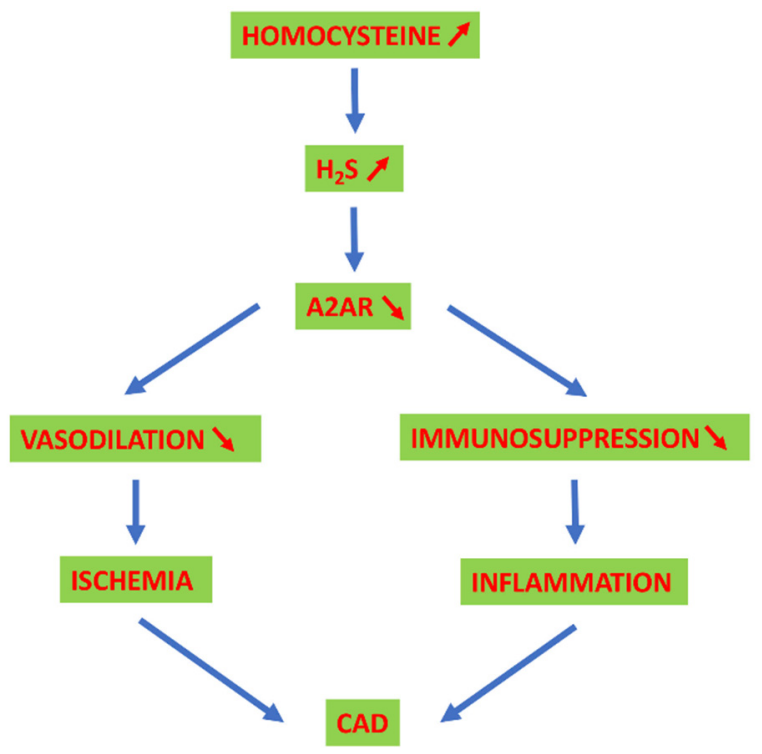

Figure 4. Proposed mechanism of the role of HHCy in CAD. In cases of CAD with $\mathrm{HHCy}, \mathrm{H}_{2} \mathrm{~S}$ accumulates in cells and reverses adenosine-induced $\mathrm{A}_{2 \mathrm{~A}} \mathrm{R}$ expression by endothelial and immune cells via the NF- $\mathrm{BB}$ pathway. Therefore, the vasodilation of the arteries and the immunosuppressive action of the lymphocytes are hampered, which promotes the processes of ischemia and inflammation, respectively, that aggravate CAD.

\section{Conclusions and Future Directions}

This article is an overview of the available evidence, which may appear partial and/or controversial, on the interaction between the adenosinergic system and the metabolism of HCy. The way in which these interactions are orchestrated in the cardiovascular system, particularly under conditions such as inflammation or hypoxia/ischemia, has highlighted the putative role of $\mathrm{H}_{2} \mathrm{~S}$ as a gas mediator in various immune/inflammatory diseases affecting the cardiovascular system, with CAD being the most characterized. These data are consistent with the hypothesis that HCy participates in CAD pathophysiology by lowering $\mathrm{A}_{2 \mathrm{~A}} \mathrm{R}$ expression on blood vessels and $\mathrm{T}$ cells to reduce coronary blood flow and promote inflammation, respectively.

This described system may be a contributor, but given all of the side effects of HHCy on CVD and the compelling evidence that $\mathrm{H}_{2} \mathrm{~S}$ protects against $\mathrm{CAD}$, it is possible that it all depends on the context and cell type. Many other factors, such as age, weight, lipid status and a family history of high blood pressure or diabetes mellitus may also interact. The question of the importance of the production of $\mathrm{H}_{2} \mathrm{~S}$ in situ or in the peripheral circulation in relation to the level of expression of transsulfuration enzymes in the cells of the cardiovascular and immune systems remains to be studied. However, measuring the level of $\mathrm{A}_{2 \mathrm{~A}} \mathrm{R}$ expression on PBMCs could offer a new risk factor for CVD. Innovative and targeted treatments on the modulation of $\mathrm{A}_{2 \mathrm{~A}} \mathrm{R}$ by $\mathrm{H}_{2} \mathrm{~S}$ could be considered.

Funding: This research was funded by ARCHANTEC Society, Marseille, France.

Acknowledgments: We thank all of the members of our laboratories and departments for their continuous support.

Conflicts of Interest: The authors declare no conflict of interest.

\section{References}

1. Mazurek, R.; Dave, J.M.; Chandran, R.R.; Misra, A.; Sheikh, A.Q.; Greif, D.M. Vascular cells in blood vessel wall development and disease. Adv. Pharmacol. 2017, 78, 323-350. [CrossRef] [PubMed]

2. Redon, J. Global cardiovascular risk assessment: Strengths and limitations. High Blood Press. Cardiovasc. Prev. 2016, 23, 87-90. [CrossRef] [PubMed] 
3. Krasi, G.; Precone, V.; Paolacci, S.; Stuppia, L.; Nodari, S.; Romeo, F.; Perrone, M.; Bushati, V.; Dautaj, A.; Bertelli, M. Genetics and pharmacogenetics in the diagnosis and therapy of cardiovascular diseases. Acta Biomed. 2019, 90, 7-19. [CrossRef] [PubMed]

4. Doughty, K.N.; Del Pilar, N.X.; Audette, A.; Katz, D.L. Lifestyle medicine and the management of cardiovascular disease. Curr. Cardiol. Rep. 2017, 19, 116. [CrossRef] [PubMed]

5. Stevens, S.L.; Wood, S.; Koshiaris, C.; Law, K.; Glasziou, P.; Stevens, R.J.; McManus, R.J. Blood pressure variability and cardiovascular disease: Systematic review and meta-analysis. BMJ 2016, 354, i4098. [CrossRef] [PubMed]

6. Ma, W.; Zhang, B.; Yang, Y.; Qi, L.; Meng, L.; Zhang, Y.; Huo, Y. Correlating the relationship between interarm systolic blood pressure and cardiovascular disease risk factors. J. Clin. Hypertens. 2017, 19, 466-471. [CrossRef]

7. Van Guldener, C.; Nanayakkara, P.W.B.; Stehouwer, C.D.A. Homocysteine and blood pressure. Curr. Hypertens. Rep. 2003, 5, 26-31. [CrossRef]

8. Schalinske, K.L.; Smazal, A.L. Homocysteine imbalance: A pathological metabolic marker. Adv. Nutr. 2012, 3, 755-762. [CrossRef]

9. Skovierova, H.; Vidomanová, E.; Mahmood, S.; Sopková, J.; Drgová, A.; Červeňová, T.; Halašová, E.; Lehotský, J. The molecular and cellular effect of homocysteine metabolism imbalance on human health. Int. J. Mol. Sci. 2016, 17, 1733. [CrossRef]

10. Selhub, J. Homocysteine metabolism. Annu. Rev. Nutr. 1999, 19, 217-246. [CrossRef]

11. Ntaios, G.; Savopoulos, C.; Grekas, D.; Hatzitolios, A. The controversial role of B-vitamins in cardiovascular risk: An update. Arch. Cardiovasc. Dis. 2009, 102, 847-854. [CrossRef]

12. Kang, S.S.; Wong, P.W.K.; Malinow, M.R. Hyperhomocyst(e)inemia as a risk factor for occlusive vascular disease. Annu. Rev. Nutr. 1992, 12, 279-298. [CrossRef]

13. Perla-Kaján, J.; Twardowski, T.; Jakubowski, H. Mechanisms of homocysteine toxicity in humans. Amino Acids 2007, 32, 561-572. [CrossRef]

14. Friedman, A.N.; Bostom, A.G.; Selhub, J.; Levey, A.S.; Rosenberg, I.H. The kidney and homocysteine metabolism. J. Am. Soc. Nephrol. 2001, 12, 2181-2189.

15. Liaugaudas, G.; Jacques, P.F.; Selhub, J.; Rosenberg, I.H.; Bostom, A.G. Renal insufficiency, vitamin B12 status, and population attributable risk for mild hyperhomocysteinemia among coronary artery disease patients in the era of folic acid-fortified cereal grain flour. Arterioscler. Thromb. Vasc. Biol. 2001, 21, 849-851. [CrossRef]

16. Ganguly, P.; Alam, S.F. Role of homocysteine in the development of cardiovascular disease. Nutr. J. 2015, 14, 6. [CrossRef]

17. Yang, Q.; He, G.W. Imbalance of homocysteine and H(2)S: Significance, mechanisms, and therapeutic promise in vascular injury. Oxidative Med. Cell. Longev. 2019, 2019, 7629673. [CrossRef]

18. Skeete, J.; Di Pette, D.J. Relationship between homocysteine and hypertension: New data add to the debate. J. Clin. Hypertens. 2017, 19, 1171-1172. [CrossRef] [PubMed]

19. Yun, L.; Xu, R.; Li, G.; Yao, Y.; Li, J.; Cong, D.; Xu, X.; Zhang, L. Homocysteine and the C677T gene polymorphism of its key metabolic enzyme MTHFR are risk factors of early renal damage in hypertension in a chinese han population. Medicine (Baltimore) 2015, 94, e2389. [CrossRef] [PubMed]

20. Sacco, R.L.; Adams, R.; Albers, G.; Alberts, M.J.; Benavente, O.; Furie, K.; Goldstein, L.B.; Gorelick, P.; Halperin, J.; Harbaugh, R.; et al. Guidelines for prevention of stroke in patients with ischemic stroke or transient ischemic attack: A statement for healthcare professionals from the American heart association/American stroke association council on stroke: Co-sponsored by the council on cardiovascular radiology and intervention: The American academy of neurology affirms the value of this guideline. Circulation 2006, 113, e409-e449. [CrossRef] [PubMed]

21. Kundi, H.; Kiziltunc, E.; Ates, I.; Cetin, M.; Barca, A.N.; Ozkayar, N.; Ornek, E. Association between plasma homocysteine levels and end-organ damage in newly diagnosed type 2 diabetes mellitus patients. Endocr. Res. 2017, 42, 36-41. [CrossRef]

22. Yang, B.; Fan, S.; Zhi, X.; Wang, Y.; Wang, Y.; Zheng, Q.; Sun, G. Prevalence of hyperhomocysteinemia in China: A systematic review and meta-analysis. Nutrients 2014, 7,74-90. [CrossRef]

23. Wang, C.; Wu, Q.; Zhang, L.; Hao, Y.; Fan, R.; Peng, X.; Liu, S.; Chen, Z.; Zhang, T.; Chen, S.; et al. Elevated total plasma homocysteine levels are associated with type 2 diabetes in women with hypertension. Asia Pac. J. Clin. Nutr. 2015, 24, 683-691. [CrossRef]

24. Handy, D.E.; Loscalzo, J. Homocysteine and atherothrombosis: Diagnosis and treatment. Curr. Atheroscler. Rep. 2003, 5, 276-283. [CrossRef]

25. Catena, C.; Colussi, G.; Nait, F.; Capobianco, F.; Sechi, L.A. Elevated homocysteine levels are associated with the metabolic syndrome and cardiovascular events in hypertensive patients. Am. J. Hypertens. 2014, 28, 943-950. [CrossRef]

26. Catena, C.; Colussi, G.; Url-Michitsch, M.; Nait, F.; Sechi, L.A. Subclinical carotid artery disease and plasma homocysteine levels in patients with hypertension. J. Am. Soc. Hypertens. 2015, 9, 167-175. [CrossRef]

27. Zhong, C.; Xu, T.; Xu, T.; Peng, Y.; Wang, A.; Wang, J.; Peng, H.; Li, Q.; Geng, D.; Zhang, D.; et al. Plasma homocysteine and prognosis of acute ischemic stroke: A gender-specific analysis from CATIS randomized clinical trial. Mol. Neurobiol. 2017, 54, 2022-2030. [CrossRef] [PubMed]

28. Montalescot, G.; Ankri, A.; Chadefaux-Vekemans, B.; Blacher, J.; Philippe, F.; Drobinski, G.; Benzidia, R.; Kamoun, P.; Thomas, D. Plasma homocysteine and the extent of atherosclerosis in patients with coronary artery disease. Int. J. Cardiol. 1997, 60, 295-300. [CrossRef]

29. Nygard, O.; Nordrehaug, J.E.; Refsum, H.; Ueland, P.M.; Farstad, M.; Vollset, S.E. Plasma homocysteine levels and mortality in patients with coronary artery disease. N. Engl. J. Med. 1997, 337, 230-237. [CrossRef] [PubMed] 
30. Yang, F.; Tan, H.M.; Wang, H. Hyperhomocysteinemia and atherosclerosis. Sheng Li Xue Bao 2005, 57, 103-114. [PubMed]

31. Ungvari, Z.; Csiszar, A.; Edwards, J.G.; Kaminski, P.M.; Wolin, M.S.; Kaley, G.; Koller, A. Increased superoxide production in coronary arteries in hyperhomocysteinemia. Arterioscler. Thromb. Vasc. Biol. 2003, 23, 418-424. [CrossRef] [PubMed]

32. Tsai, J.C.; Wang, H.; Perrella, M.A.; Yoshizumi, M.; Sibinga, N.E.; Tan, L.C.; Haber, E.; Chang, T.H.; Schlegel, R.; Lee, M.E. Induction of cyclin A gene expression by homocysteine in vascular smooth muscle cells. J. Clin. Investig. 1996, 97, 146-153. [CrossRef] [PubMed]

33. Liao, D.; Tan, H.; Hui, R.; Li, Z.; Jiang, X.; Gaubatz, J.; Yang, F.; Durante, W.; Chan, L.; Schafer, A.I.; et al. Hyperhomocysteinemia decreases circulating high-density lipoprotein by inhibiting apolipoprotein A-I Protein synthesis and enhancing HDL cholesterol clearance. Circ. Res. 2006, 99, 598-606. [CrossRef] [PubMed]

34. Jakubowski, H. The pathophysiological hypothesis of homocysteine thiolactone-mediated vascular disease. J. Physiol. Pharmacol. 2008, 9, 155-167.

35. Undas, A.; Brożek, J.; Jankowski, M.; Siudak, Z.; Szczeklik, A.; Jakubowski, H. Plasma homocysteine affects fibrin clot permeability and resistance to lysis in human subjects. Arterioscler. Thromb. Vasc. Biol. 2006, 26, 1397-1404. [CrossRef]

36. Elsherbiny, N.M.; Sharma, I.; Kira, D.; Alhusban, S.; Samra, Y.A.; Jadeja, R.; Martin, P.; Al-Shabrawey, M.; Tawfik, A. Homocysteine induces inflammation in retina and brain. Biomolecules 2020, 10, 393. [CrossRef]

37. Wald, D.S.; Wald, N.J.; Morris, J.K.; Law, M. Folic acid, homocysteine, and cardiovascular disease: Judging causality in the face of inconclusive trial evidence. BMJ 2006, 333, 1114-1117. [CrossRef]

38. Faverzani, J.L.; Hammerschmidt, T.G.; Sitta, A.; Deon, M.; Wajner, M.; Vargas, C.R. Oxidative stress in homocystinuria due to cystathionine $ß$-synthase deficiency: Findings in patients and in animal models. Cell. Mol. Neurobiol. 2017, 37, 1477-1485. [CrossRef]

39. Stuhlinger, M.C.; Tsao, P.S.; Her, J.H.; Kimoto, M.; Balint, R.F.; Cooke, J.P. Homocysteine impairs the nitric oxide synthase pathway: Role of asymmetric dimethylarginine. Circulation 2001, 104, 2569-2575. [CrossRef]

40. Pushpakumar, S.; Kundu, S.; Sen, U. Endothelial dysfunction: The link between homocysteine and hydrogen sulfide. Curr. Med. Chem. 2014, 21, 3662-3672. [CrossRef]

41. Castro, R.; Rivera, I.; Struys, E.A.; Jansen, E.E.W.; Ravasco, P.; Camilo, M.E.; Blom, H.J.; Jakobs, C.; Tavaresde Almeida, I. Increased homocysteine and S-adenosylhomocysteine concentrations and DNA hypomethylation in vascular disease. Clin. Chem. 2003, 49, 1292-1296. [CrossRef]

42. Choumenkovitch, S.F.; Selhub, J.; Bagley, P.J.; Maeda, N.; Nadeau, M.R.; Smith, D.E.; Choi, S.-W. In the cystathionine betasynthase knockout mouse, elevations in total plasma homocysteine increase tissue S-adenosylhomocysteine, but responses of S-adenosylmethionine and DNA methylation are tissue specific. J. Nutr. 2002, 132, 2157-2160. [CrossRef] [PubMed]

43. Jacobsen, D.W. Homocysteine and vitamins in cardiovascular disease. Clin. Chem. 1998, 44, 1833-1843. [CrossRef] [PubMed]

44. Büdy, B.; O’Neill, R.; Di Bello, P.M.; Sengupta, S.; Jacobsen, D.W. Homocysteine transport by human aortic endothelial cells: Identification and properties of import systems. Arch. Biochem. Biophys. 2006, 446, 119-130. [CrossRef] [PubMed]

45. Paul, B.D.; Snyder, S.H. $\mathrm{H}_{2}$ S signalling through protein sulfhydration and beyond. Nat. Rev. Mol. Cell Biol. 2012, 13, 499-507. [CrossRef]

46. Kimura, H. Hydrogen sulfide: Its production, release and functions. Amino Acids 2010, 41, 113-121. [CrossRef]

47. Giuffrè, A.; Vicente, J.B. Hydrogen sulfide biochemistry and interplay with other gaseous mediators in mammalian physiology. Oxidative Med. Cell. Longev. 2018, 2018, 6290931. [CrossRef]

48. Chen, X.; Jhee, K.H.; Kruger, W.D. Production of the neuromodulator H2S by cystathionine $\beta$-synthase via the condensation of cysteine and homocysteine. J. Biol. Chem. 2004, 279, 52082-52086. [CrossRef]

49. Chiku, T.; Padovani, D.; Zhu, W.; Singh, S.; Vitvitsky, V.; Banerjee, R. $\mathrm{H}_{2} \mathrm{~S}$ biogenesis by human cystathionine gamma-lyase leads to the novel sulfur metabolites lanthionine and homolanthionine and is responsive to the grade of hyperhomocysteinemia. J. Biol. Chem. 2009, 284, 11601-11612. [CrossRef] [PubMed]

50. Shibuya, N.; Tanaka, M.; Yoshida, M.; Ogasawara, Y.; Ishii, K.; Kimura, H.; Togawa, T. 3-mercaptopyruvate sulfurtransferase produces hydrogen sulfide and bound sulfane sulfur in the brain. Antioxid. Redox Signal. 2009, 11, 703-714. [CrossRef] [PubMed]

51. Singh, S.; Banerjee, R. PLP-dependent H(2)S biogenesis. Biochim. Biophys. Acta (BBA) Proteins Proteom. 2011, 1814, 1518-1527. [CrossRef] [PubMed]

52. Shibuya, N.; Koike, S.; Tanaka, M.; Ishigami-Yuasa, M.; Kimura, Y.; Ogasawara, Y.; Fukui, K.; Nagahara, N.; Kimura, H. A novel pathway for the production of hydrogen sulfide from D-cysteine in mammalian cells. Nat. Commun. 2013, 4, 1366. [CrossRef] [PubMed]

53. Chen, P.; Poddar, R.; Tipa, E.V.; Dibello, P.M.; Moravec, C.D.; Robinson, K.; Green, R.; Kruger, W.D.; Garrow, T.A.; Jacobsen, D.W. Homocysteine metabolism in cardiovascular cells and tissues: Implications for hyperhomocysteinemia and cardiovascular disease. Adv. Enzyme Regul. 1999, 39, 93-109. [CrossRef]

54. Tipa, E.V.; Chen, P.; Majors, A.K.; Robinson, K.; Jacobsen, D.W. Failure of homocysteine to restore the glutathione (GHS) pool in cysteine-starved human aortic endothelial cells (HAEC). FASEB J. 2000, 14, A460.

55. Sørensen, J.T.; Gaustadnes, M.; Stabler, S.P.; Allen, R.H.; Mudd, S.H.; Hvas, A.M. Molecular and biochemical investigations of patients with intermediate or severe hyperhomocysteinemia. Mol. Genet. Metab. 2016, 117, 344-350. [CrossRef] [PubMed]

56. Wang, R. Physiological implications of hydrogen sulfide: A whiff exploration that blossomed. Physiol. Rev. 2012, 92, 791-896. [CrossRef] 
57. Chertok, V.M.; Kotsyuba, A.E. Distribution of H2S synthesis enzymes in the walls of cerebral arteries in rats. Bull. Exp. Biol. Med. 2012, 154, 104-107. [CrossRef]

58. Shibuya, N.; Mikami, Y.; Kimura, Y.; Nagahara, N.; Kimura, H. Vascular endothelium expresses 3-mercaptopyruvate sulfurtransferase and produces hydrogen sulfide. J. Biochem. 2009, 146, 623-626. [CrossRef]

59. Masi, A.d.; Ascenzi, P. H ${ }_{2}$ S: A “Double face" molecule in health and disease. Biofactors 2012, 39, 186-196. [CrossRef]

60. Lo Faro, M.L.; Fox, B.; Whatmore, J.L.; Winyard, P.G.; Whiteman, M. Hydrogen sulfide and nitric oxide interactions in inflammation. Nitric Oxide 2014, 41, 38-47. [CrossRef]

61. Cortese-Krott, M.M.; Koning, A.; Kuhnle, G.G.C.; Nagy, P.; Bianco, C.L.; Pasch, A.; Wink, D.A.; Fukuto, J.M.; Jackson, A.A.; van Goor, H.; et al. The reactive species interactome: Evolutionary emergence, biological significance, and opportunities for redox metabolomics and personalized medicine. Antioxid. Redox Signal. 2017, 27, 684-712. [CrossRef]

62. Kevil, C.; Cortese-Krott, M.M.; Nagy, P.; Papapetropoulos, A.; Feelisch, M.; Szabo, C. Cooperative interactions between NO and $\mathrm{H}_{2} \mathrm{~S}$ : Chemistry, biology, physiology, pathophysiology. In Nitric Oxide; Ignarro, L., Freeman, B., Eds.; Elsevier: London, UK, 2017; pp. 57-83.

63. Szabo, C. Hydrogen sulfide, an enhancer of vascular nitric oxide signaling: Mechanisms and implications. Am. J. Physiol. Cell Physiol. 2017, 312, C3-C15. [CrossRef] [PubMed]

64. Korbut, E.; Brzozowski, T.; Magierowski, M. Carbon monoxide being hydrogen sulfide and nitric oxide molecular sibling, as endogenous and exogenous modulator of oxidative stress and antioxidative mechanisms in the digestive system. Oxidative Med. Cell. Longev. 2020, 2020, 5083876. [CrossRef] [PubMed]

65. Lowicka, E.; Beltowski, J. Hydrogen sulfide $\left(\mathrm{H}_{2} \mathrm{~S}\right)$ - the third gas of interest for pharmacologists. Pharmacol. Rep. 2007, 59, 4-24. [PubMed]

66. Andreadou, I.; Schulz, R.; Papapetropoulos, A.; Turan, B.; Ytrehus, K.; Ferdinandy, P.; Daiber, A.; Di Lisa, F. The role of mitochondrial reactive oxygen species, $\mathrm{NO}$ and $\mathrm{H}(2) \mathrm{S}$ in ischaemia/reperfusion injury and cardioprotection. J. Cell. Mol. Med. 2020, 24, 6510-6522. [CrossRef] [PubMed]

67. Szabo, C.; Papapetropoulos, A. International union of basic and clinical pharmacology. CII: Pharmacological modulation of H(2)S levels: $\mathrm{H}(2) \mathrm{S}$ donors and H(2)S biosynthesis inhibitors. Pharmacol. Rev. 2017, 69, 497-564. [CrossRef]

68. Polhemus, D.J.; Lefer, D.J. Emergence of hydrogen sulfide as an endogenous gaseous signaling molecule in cardiovascular disease. Circ. Res. 2014, 114, 730-737. [CrossRef]

69. Nicholls, P.; Marshall, D.C.; Cooper, C.E.; Wilson, M.T. Sulfide inhibition of and metabolism by cytochrome c oxidase. Biochem. Soc. Trans. 2013, 41, 1312-1316. [CrossRef]

70. Sun, H.J.; Wu, Z.Y.; Cao, L.; Zhu, M.Y.; Liu, T.T.; Guo, L.; Lin, Y.; Nie, X.W.; Bian, J.S. Hydrogen sulfide: Recent progression and perspectives for the treatment of diabetic nephropathy. Molecules 2019, 24, 2857. [CrossRef]

71. Giuffrè, A.; Tomé, C.S.; Fernandes, D.G.F.; Zuhra, K.; Vicente, J.B. Hydrogen sulfide metabolism and signaling in the tumor microenvironment. Adv. Exp. Med. Biol. 2020, 1219, 335-353. [CrossRef]

72. Augsburger, F.; Szabo, C. Potential role of the 3-mercaptopyruvate sulfurtransferase (3-MST)-hydrogen sulfide $\left(\mathrm{H}_{2} \mathrm{~S}\right)$ pathway in cancer cells. Pharmacol. Res. 2020, 154, 104083. [CrossRef]

73. Li, H.; Xu, F.; Gao, G.; Gao, X.; Wu, B.; Zheng, C.; Wang, P.; Li, Z.; Hua, H.; Li, D. Hydrogen sulfide and its donors: Novel antitumor and antimetastatic therapies for triple-negative breast cancer. Redox Biol. 2020, 34, 101564. [CrossRef]

74. Sun, H.J.; Wu, Z.Y.; Nie, X.W.; Bian, J.S. Role of endothelial dysfunction in cardiovascular diseases: The link between inflammation and hydrogen sulfide. Front. Pharmacol. 2020, 10, 1568. [CrossRef]

75. Sunzini, F.; De Stefano, S.; Chimenti, M.S.; Melino, S. Hydrogen sulfide as potential regulatory gasotransmitter in arthritic diseases. Int. J. Mol. Sci. 2020, 21, E1180. [CrossRef]

76. Szabo, C. The re-emerging pathophysiological role of the cystathionine- $\beta$-synthase-hydrogen sulfide system in Down syndrome. FEBS J. 2020, 287, 3150-3160. [CrossRef] [PubMed]

77. Tabassum, R.; Jeong, N.Y.; Jung, J. Therapeutic importance of hydrogen sulfide in age-associated neurodegenerative diseases. Neural Regen. Res. 2020, 15, 653-662. [CrossRef] [PubMed]

78. Yang, N.; Liu, Y.; Li, T.; Tuo, Q. Role of hydrogen sulfide in chronic diseases. DNA Cell Biol. 2020, 39, 187-196. [CrossRef]

79. Mani, S.; Li, H.; Untereiner, A.; Wu, L.; Yang, G.; Austin, R.C.; Dickhout, J.G.; Lhoták, Š.; Meng, Q.H.; Wang, R. Decreased endogenous production of hydrogen sulfide accelerates atherosclerosis. Circulation 2013, 127, 2523-2534. [CrossRef] [PubMed]

80. Possomato-Vieira, J.S.; Gonçalves-Rizzi, V.H.; do Nascimento, R.A.; Wandekin, R.R.; Caldeira-Dias, M.; Chimini, J.S.; da Silva, M.L.S.; Dias-Junior, C.A. Clinical and experimental evidences of hydrogen sulfide involvement in lead-induced hypertension. BioMed Res. Int. 2018, 2018, 4627391. [CrossRef] [PubMed]

81. Kanagy, N.L.; Szabo, C.; Papapetropoulos, A. Vascular biology of hydrogen sulfide. Am. J. Physiol. Cell Physiol. 2017, 312, C537-C549. [CrossRef]

82. Fu, Y.; Wang, X.; Kong, W. Hyperhomocysteinaemia and vascular injury: Advances in mechanisms and drug targets. Br. J. Pharmacol. 2018, 175, 1173-1189. [CrossRef]

83. Li, J.J.; Li, Q.; Du, H.P.; Wang, Y.L.; You, S.J.; Wang, F.; Xu, X.S.; Cheng, J.; Cao, Y.J.; Liu, C.F.; et al. Homocysteine triggers inflammatory responses in macrophages through inhibiting CSE-H2S signaling via DNA hypermethylation of CSE promoter. Int. J. Mol. Sci. 2015, 16, 12560-12577. [CrossRef] 
84. Li, M.H.; Tang, J.P.; Zhang, P.; Li, X.; Wang, C.Y.; Wei, H.J.; Yang, X.F.; Zou, W.; Tang, X.Q. Disturbance of endogenous hydrogen sulfide generation and endoplasmic reticulum stress in hippocampus are involved in homocysteine-induced defect in learning and memory of rats. Behav. Brain Res. 2014, 262, 35-41. [CrossRef]

85. Tang, X.Q.; Shen, X.T.; Huang, Y.E.; Chen, R.Q.; Ren, Y.K.; Fang, H.R.; Zhuang, Y.Y.; Wang, C.Y. Inhibition of endogenous hydrogen sulfide generation is associated with homocysteine-induced neurotoxicity: Role of ERK1/2 activation. J. Mol. Neurosci. 2010, 45, 60-67. [CrossRef]

86. d'Emmanuele di Villa Bianca, R.; Mitidieri, E.; Di Minno, M.N.D.; Kirkby, N.S.; Warner, T.D.; Di Minno, G.; Cirino, G.; Sorrentino, R. Hydrogen sulphide pathway contributes to the enhanced human platelet aggregation in hyperhomocysteinemia. Proc. Natl. Acad. Sci. USA 2013, 110, 15812-15817. [CrossRef]

87. Cui, X.; Navneet, S.; Wang, J.; Roon, P.; Chen, W.; Xian, M.; Smith, S.B. Analysis of MTHFR, CBS, glutathione, taurine, and hydrogen sulfide levels in retinas of hyperhomocysteinemic mice. Investig. Ophthalmol. Vis. Sci. 2017, 58, 1954-1963. [CrossRef]

88. Chen, L.; Ingrid, S.; Ding, Y.G.; Liu, Y.; Qi, J.G.; Tang, C.S.; Du, J.B. Imbalance of endogenous homocysteine and hydrogen sulfide metabolic pathway in essential hypertensive children. Chin. Med. J. 2007, 120, 389-393. [CrossRef] [PubMed]

89. Sun, L.; Sun, S.; Lietal, Y. Potential biomarkers predicting risk of pulmonary hypertension in congenital heart disease: The role of homocysteine and hydrogen sulfide. Chin. Med. J. 2014, 127, 893-899. [PubMed]

90. He, Y.; Liu, S.; Zhang, Z.; Liao, C.; Lin, F.; Yao, W.; Chen, Y. Imbalance of endogenous hydrogen sulfide and homocysteine in chronic obstructive pulmonary disease combined with cardiovascular disease. Front. Pharmacol. 2017, 8, 624. [CrossRef] [PubMed]

91. Kabil, O.; Banerjee, R. Redox biochemistry of hydrogen sulfide. J. Biol. Chem. 2010, 285, 21903-21907. [CrossRef]

92. Wagner, C.A. Hydrogen sulfide: A new gaseous signal molecule and blood pressure regulator. J. Nephrol. 2009, $22,173-176$.

93. Deplancke, B.; Gaskins, H.R. Hydrogen sulfide induces serum-independent cell cycle entry in nontransformed rat intestinal epithelial cells. FASEB J. 2003, 17, 1310-1312. [CrossRef]

94. Du, J.; Hui, Y.; Cheung, Y.; Bin, G.; Jiang, H.; Chen, X.; Tang, C. The possible role of hydrogen sulfide as a smooth muscle cell proliferation inhibitor in rat cultured cells. Heart Vessels 2004, 19, 75-80. [CrossRef] [PubMed]

95. Yang, G.; Cao, K.; Wu, L.; Wang, R. Cystathionine $\gamma$-lyase overexpression inhibits cell proliferation via a H2S-dependent modulation of ERK1/2 phosphorylation and p21Cip/WAK-1. J. Biol. Chem. 2004, 279, 49199-49205. [CrossRef] [PubMed]

96. Yang, G.; Sun, X.; Wang, R. Hydrogen sulfide-induced apoptosis of human aorta smooth muscle cells via the activation of mitogen-activated protein kinases and caspase-3. FASEB J. 2004, 18, 1782-1784. [CrossRef]

97. Yang, G.; Wu, L.; Wang, R. Pro-apoptotic effect of endogenous H2S on human aorta smooth muscle cells. FASEB J. 2006, 20, 553-555. [CrossRef]

98. Zanardo, R.C.O.; Brancaleone, V.; Distrutti, E.; Fiorucci, S.; Cirino, G.; Wallace, J.L.; Zanardo, R.C.O.; Brancaleone, V.; Distrutti, E.; Fiorucci, S.; et al. Hydrogen sulfide is an endogenous modulator of leukocyte-mediated inflammation. FASEB J. 2006, 20, 2118-2120. [CrossRef]

99. Bhatia, M.; Sidhapuriwala, J.; Moochhala, S.M.; Moore, P.K. Hydrogen sulphide is a mediator of carrageenan-induced hindpaw oedema in the rat. Br. J. Pharmacol. 2005, 145, 141-144. [CrossRef]

100. Rinaldi, L.; Gobbi, G.; Pambianco, M.; Micheloni, C.; Mirandola, P.; Vitale, M. Hydrogen sulfide prevents apoptosis of human PMN via inhibition of p38 and caspase 3. Lab. Investig. 2006, 86, 391-397. [CrossRef] [PubMed]

101. Lyons, J.; Rauh-Pfeiffer, A.; Ming-Yu, Y.; Lu, X.M.; Zurakowski, D.; Curley, M.; Collier, S.; Duggan, C.; Nurko, S.; Thompson, J.; et al. Cysteine metabolism and whole blood glutathione synthesis in septic pediatric patients. Crit. Care Med. 2001, 29, 870-877. [CrossRef]

102. Wang, Y.; Yu, R.; Wu, L.; Yang, G. Hydrogen sulfide signaling in regulation of cell behaviors. Nitric Oxide 2020, 103, 9-19. [CrossRef]

103. Dilek, N.; Papapetropoulos, A.; Toliver-Kinsky, T.; Szabo, C. Hydrogen sulfide: An endogenous regulator of the immune system. Pharmacol. Res. 2020, 161, 105119. [CrossRef]

104. Zhu, X.Y.; Liu, S.J.; Liu, Y.J.; Wang, S.; Ni, X. Glucocorticoids suppress cystathionine gamma-lyase expression and H2S production in lipopolysaccharide-treated macrophages. Cell. Mol. Life Sci. 2010, 67, 1119-1132. [CrossRef]

105. George, L.; Ramasamy, T.; Sirajudeen, K.N.S.; Manickam, V. LPS-induced apoptosis is partially mediated by hydrogen sulphide in RAW 264.7 murine macrophages. Immunol. Investig. 2019, 48, 451-465. [CrossRef]

106. Wang, X.H.; Wang, F.; You, S.J.; Cao, Y.J.; Cao, L.D.; Han, Q.; Liu, C.F.; Hu, L.F. Dysregulation of cystathionine $\gamma$-lyase (CSE)/hydrogen sulfide pathway contributes to ox-LDL-induced inflammation in macrophage. Cell. Signal. 2013, 25, $2255-2262$. [CrossRef] [PubMed]

107. He, D.; Liu, F.; Cui, S.; Jiang, N.; Yu, H.; Zhou, Y.; Liu, Y.; Kou, X. Mechanical load-induced H(2)S production by periodontal ligament stem cells activates M1 macrophages to promote bone remodeling and tooth movement via STAT1. Stem Cell Res. Ther. 2020, 11, 112. [CrossRef]

108. Zheng, Y.; Luo, N.; Mu, D.; Jiang, P.; Liu, R.; Sun, H.; Xiong, S.; Liu, X.; Wang, L.; Chu, Y. Lipopolysaccharide regulates biosynthesis of cystathionine $\gamma$-lyase and hydrogen sulfide through toll-like receptor-4/p38 and toll-like receptor-4/NF- $\mathrm{B}$ pathways in macrophages. In Vitro Cell. Dev. Biol. Anim. 2013, 49, 679-688. [CrossRef] [PubMed]

109. Badiei, A.; Gieseg, S.; Davies, S.; Othman, M.I.; Bhatia, M. LPS up-regulates cystathionine $\gamma$-lyase gene expression in primary human macrophages via NF-кB/ERK pathway. Inflamm. Allergy Drug Targets 2015, 14, 99-104. [CrossRef] [PubMed] 
110. Miller, T.W.; Wang, E.A.; Gould, S.; Stein, E.V.; Kaur, S.; Lim, L.; Amarnath, S.; Fowler, D.H.; Roberts, D.D. Hydrogen sulfide is an endogenous potentiator of T cell activation. J. Biol. Chem. 2012, 287, 4211-4221. [CrossRef] [PubMed]

111. Kida, K.; Ichinose, F. Hydrogen sulfide and neuroinflammation. Handb. Exp. Pharmacol. 2015, 230, 181-189. [CrossRef]

112. Zhang, J.Y.; Ding, Y.P.; Wang, Z.; Kong, Y.; Gao, R.; Chen, G. Hydrogen sulfide therapy in brain diseases: From bench to bedside. Med. Gas Res. 2017, 7, 113-119. [CrossRef]

113. Rivers, J.R.; Badiei, A.; Bhatia, M. Hydrogen sulfide as a therapeutic target for inflammation. Expert Opin. Ther. Targets 2012, 16, 439-449. [CrossRef]

114. Bhatia, M. H2S and substance P in inflammation. Methods Enzymol. 2015, 555, 195-205. [CrossRef]

115. Guo, F.F.; Yu, T.C.; Hong, J.; Fang, J.Y. Emerging roles of hydrogen sulfide in inflammatory and neoplastic colonic diseases. Front. Physiol. 2016, 7, 156. [CrossRef]

116. Burguera, E.F.; Meijide-Failde, R.; Blanco, F.J. Hydrogen sulfide and inflammatory joint diseases. Curr. Drug Targets 2017, 18, 1641-1652. [CrossRef] [PubMed]

117. Feliers, D.; Lee, H.J.; Kasinath, B.S. Hydrogen sulfide in renal physiology and disease. Antioxid. Redox Signal. 2016, $25,720-731$. [CrossRef] [PubMed]

118. Cao, X.; Bian, J.S. The role of hydrogen sulfide in renal system. Front. Pharmacol. 2016, 7, 385. [CrossRef] [PubMed]

119. Pan, L.L.; Qin, M.; Liu, X.H.; Zhu, Y.Z. The role of hydrogen sulfide on cardiovascular homeostasis: An overview with update on immunomodulation. Front. Pharmacol. 2017, 8, 686. [CrossRef]

120. Shefa, U.; Yeo, S.G.; Kim, M.S.; Song, I.O.; Jung, J.; Jeong, N.Y.; Huh, Y. Role of gasotransmitters in oxidative stresses, neuroinflammation, and neuronal repair. BioMed Res. Int. 2017, 2017, 1689341. [CrossRef]

121. Han, Y.; Shang, Q.; Yao, J.; Ji, Y. Hydrogen sulfide: A gaseous signaling molecule modulates tissue homeostasis: Implications in ophthalmic diseases. Cell Death Dis. 2019, 10, 293. [CrossRef]

122. He, J.T.; Li, H.; Yang, L.; Mao, C.Y. Role of hydrogen sulfide in cognitive deficits: Evidences and mechanisms. Eur. J. Pharmacol. 2019, 849, 146-153. [CrossRef]

123. Coavoy-Sánchez, S.A.; Costa, S.K.P.; Muscará, M.N. Hydrogen sulfide and dermatological diseases. Br. J. Pharmacol. 2020, 177, 857-865. [CrossRef]

124. Bruzzese, L.; Fromonot, J.; By, Y.; Durand-Gorde, J.M.; Condo, J.; Kipson, N.; Guieu, R.; Fenouillet, E.; Ruf, J. NF-kB enhances hypoxia-driven T-cell immunosuppression via upregulation of adenosine A2A receptors. Cell. Signal. 2014, 26, 1060-1067. [CrossRef] [PubMed]

125. Burnstock, G. Purinergic signalling-an overview. In Novartis Foundation Symposia; Burnstock, G., Ed.; John Wiley \& Sons, Ltd.: Chichester, UK, 2008; pp. 26-48.

126. Paganelli, F.; Gaudry, M.; Ruf, J.; Guieu, R. Recent advances in the role of the adenosinergic system in coronary artery disease. Cardiovasc. Res. 2020, cvaa275. [CrossRef] [PubMed]

127. Borea, P.A.; Gessi, S.; Merighi, S.; Vincenzi, F.; Varani, K. Pharmacology of adenosine receptors: The state of the art. Physiol. Rev. 2018, 98, 1591-1625. [CrossRef]

128. Queiroz, G.; Talaia, C.; Gonçalves, J. Adenosine A2A receptor-mediated facilitation of noradrenaline release involves protein kinase $\mathrm{C}$ activation and attenuation of presynaptic inhibitory receptor-mediated effects in the rat vas deferens. J. Neurochem. 2003, 85, 740-748. [CrossRef]

129. Ruf, J.; Paganelli, F.; Bonello, L.; Kipson, N.; Mottola, G.; Fromonot, J.; Condo, J.; Boussuges, A.; Bruzzese, L.; Kerbaul, F.; et al. Spare adenosine A2a receptors are associated with positive exercise stress test in coronary artery disease. Mol. Med. 2016, 22, 530-536. [CrossRef]

130. Conlon, B.A. Advances in understanding adenosine as a plurisystem modulator in sepsis and the systemic inflammatory response syndrome (SIRS). Front. Biosci. 2005, 10, 2548-2565. [CrossRef]

131. Fredholm, B.B. Adenosine receptors as targets for drug development. Drug News Perspect. 2003, 16, 283-289. [CrossRef] [PubMed]

132. Baldwin, S.A.; Yao, S.Y.M.; Hyde, R.J.; Ng, A.M.L.; Foppolo, S.; Barnes, K.; Ritzel, M.W.L.; Cass, C.E.; Young, J.D. Functional characterization of novel human and mouse equilibrative nucleoside transporters (hENT3 and mENT3) located in intracellular membranes. J. Biol. Chem. 2005, 280, 15880-15887. [CrossRef] [PubMed]

133. Baldwin, S.A.; Beal, P.R.; Yao, S.Y.; King, A.E.; Cass, C.E.; Young, J.D. The equilibrative nucleoside transporter family, SLC29. Pflug. Arch. Eur. J. Physiol. 2004, 447, 735-743. [CrossRef]

134. Young, J.D.; Yao, S.Y.M.; Baldwin, J.M.; Cass, C.E.; Baldwin, S.A. The human concentrative and equilibrative nucleoside transporter families, SLC28 and SLC29. Mol. Asp. Med. 2013, 34, 529-547. [CrossRef]

135. Peleli, M.; Carlstrom, M. Adenosine signaling in diabetes mellitus and associated cardiovascular and renal complications. Mol. Asp. Med. 2017, 55, 62-74. [CrossRef]

136. Fenouillet, E.; Mottola, G.; Kipson, N.; Paganelli, F.; Guieu, R.; Ruf, J. Adenosine receptor profiling reveals an association between the presence of spare receptors and cardiovascular disorders. Int. J. Mol. Sci. 2019, 20, 5964. [CrossRef]

137. Gaudry, M.; Vairo, D.; Marlinge, M.; Gaubert, M.; Guiol, C.; Mottola, G.; Gariboldi, V.; Deharo, P.; Sadrin, S.; Maixent, J.M.; et al. Adenosine and its receptors: An expected tool for the diagnosis and treatment of coronary artery and ischemic heart diseases. Int. J. Mol. Sci. 2020, 21, 5321. [CrossRef]

138. Haskó, G.; Linden, J.; Cronstein, B.; Pacher, P. Adenosine receptors: Therapeutic aspects for inflammatory and immune diseases. Nat. Rev. Drug Discov. 2008, 7, 759-770. [CrossRef] [PubMed] 
139. Bowser, J.L.; Lee, J.W.; Yuan, X.; Eltzschig, H.K. The hypoxia-adenosine link during inflammation. J. Appl. Physiol. 2017, 123, 1303-1320. [CrossRef]

140. Singh, L.; Kulshrestha, R.; Singh, N.; Jaggi, A.S. Mechanisms involved in adenosine pharmacological preconditioning-induced cardioprotection. Korean J. Physiol. Pharmacol. 2018, 22, 225-234. [CrossRef] [PubMed]

141. Fredholm, B.B.; Yang, J.; Wang, Y. Low, but not high, dose caffeine is a readily available probe for adenosine actions. Mol. Asp. Med. 2017, 55, 20-25. [CrossRef] [PubMed]

142. Akash, M.S.H.; Rehman, K.; Chen, S. Effects of coffee on type 2 diabetes mellitus. Nutrition 2014, 30, 755-763. [CrossRef] [PubMed]

143. Kempf, K.; Herder, C.; Erlund, I.; Kolb, H.; Martin, S.; Carstensen, M.; Koenig, W.; Sundvall, J.; Bidel, S.; Kuha, S.; et al. Effects of coffee consumption on subclinical inflammation and other risk factors for type 2 diabetes: A clinical trial. Am. J. Clin. Nutr. 2010, 91, 950-957. [CrossRef]

144. Varani, K.; Portaluppi, F.; Gessi, S.; Merighi, S.; Ongini, E.; Belardinelli, L.; Borea, P.A. Dose and time effects of caffeine intake on human platelet adenosine A(2A) receptors: Functional and biochemical aspects. Circulation 2000, 102, 285-289. [CrossRef]

145. Awad, A.S.; Huang, L.; Ye, H.; Duong, E.T.A.; Bolton, W.K.; Linden, J.; Okusa, M.D. Adenosine A2A receptor activation attenuates inflammation and injury in diabetic nephropathy. Am. J. Physiol. Ren. Physiol. 2006, 290, F828-F837. [CrossRef]

146. Persson, P.; Friederich-Persson, M.; Fasching, A.; Hansell, P.; Inagi, R.; Palm, F. Adenosine A2a receptor stimulation prevents proteinuria in diabetic rats by promoting an anti-inflammatory phenotype without affecting oxidative stress. Acta Physiol. 2015, 214, 311-318. [CrossRef]

147. Cekic, C.; Linden, J. Purinergic regulation of the immune system. Nat. Rev. Immunol. 2016, 16, 177-192. [CrossRef]

148. Csóka, B.; Németh, Z.H.; Virág, L.; Gergely, P.; Leibovich, S.J.; Pacher, P.; Sun, C.X.; Blackburn, M.R.; Vizi, E.S.; Deitch, E.A.; et al. A2A adenosine receptors and C/EBPbeta are crucially required for IL-10 production by macrophages exposed to Escherichia coli. Blood 2007, 110, 2685-2695. [CrossRef]

149. Koscsó, B.; Csóka, B.; Kókai, E.; Németh, Z.H.; Pacher, P.; Virág, L.; Leibovich, S.J.; Haskó, G. Adenosine augments IL-10-induced STAT3 signaling in M2c macrophages. J. Leukoc. Biol. 2013, 94, 1309-1315. [CrossRef] [PubMed]

150. Akash, M.S.H.; Rehman, K.; Chen, S. Role of inflammatory mechanisms in pathogenesis of type 2 diabetes mellitus. J. Cell. Biochem. 2013, 114, 525-531. [CrossRef] [PubMed]

151. Donath, M.Y.; Shoelson, S.E. Type 2 diabetes as an inflammatory disease. Nat. Rev. Immunol. 2011, 11, 98-107. [CrossRef] [PubMed]

152. Esser, N.; Paquot, N.; Scheen, A.J. Anti-inflammatory agents to treat or prevent type 2 diabetes, metabolic syndrome and cardiovascular disease. Expert Opin. Investig. Drugs 2014, 24, 283-307. [CrossRef] [PubMed]

153. Yang, T.; Zollbrecht, C.; Winerdal, M.E.; Zhuge, Z.; Zhang, X.M.; Terrando, N.; Checa, A.; Sällström, J.; Wheelock, C.E.; Winqvist, O.; et al. Genetic abrogation of adenosine A3 receptor prevents uninephrectomy and high salt-induced hypertension. J. Am. Heart Assoc. 2016, 5, e003868. [CrossRef] [PubMed]

154. Burnstock, G.; Boeynaems, J.M. Purinergic signalling and immune cells. Purinergic Signal. 2014, 10, 529-564. [CrossRef] [PubMed]

155. Thiel, M.; Caldwell, C.C.; Sitkovsky, M.V. The critical role of adenosine A2A receptors in downregulation of inflammation and immunity in the pathogenesis of infectious diseases. Microbes Infect. 2003, 5, 515-526. [CrossRef]

156. Barletta, K.E.; Ley, K.; Mehrad, B. Regulation of neutrophil function by adenosine. Arterioscler. Thromb. Vasc. Biol. 2012, 32, 856-864. [CrossRef]

157. Cronstein, B.N.; Levin, R.I.; Philips, M.; Hirschhorn, R.; Abramson, S.B.; Weissmann, G. Neutrophil adherence to endothelium is enhanced via adenosine A1 receptors and inhibited via adenosine A2 receptors. J. Immunol. 1992, 148, $2201-2206$.

158. Sullivan, G.W.; Lee, D.D.; Ross, W.G.; DiVietro, J.A.; Lappas, C.M.; Lawrence, M.B.; Linden, J. Activation of A2Aadenosine receptors inhibits expression of $\alpha 4 / \beta 1$ integrin (very late antigen-4) on stimulated human neutrophils. J. Leukoc. Biol. 2003, 75, 127-134. [CrossRef]

159. Thiel, M.; Chambers, J.D.; Chouker, A.; Fischer, S.; Zourelidis, C.; Bardenheuer, H.J.; Arfors, K.E.; Peter, K. Effect of adenosine on the expression of $\beta 2$ integrins and L-selectin of human polymorphonuclear leukocytes in vitro. J. Leukoc. Biol. 1996, 59, 671-682. [CrossRef]

160. Sevigny, C.P.; Li, L.; Awad, A.S.; Huang, L.; McDuffie, M.; Linden, J.; Lobo, P.I.; Okusa, M.D. Activation of adenosine 2A receptors attenuates allograft rejection and alloantigen recognition. J. Immunol. 2007, 178, 4240-4249. [CrossRef]

161. Day, Y.J.; Li, Y.; Rieger, J.M.; Ramos, S.I.; Okusa, M.D.; Linden, J. A2A adenosine receptors on bone marrow-derived cells protect liver from ischemia-reperfusion injury. J. Immunol. 2005, 174, 5040-5046. [CrossRef]

162. Reutershan, J.; Cagnina, R.E.; Chang, D.; Linden, J.; Ley, K. Therapeutic anti-inflammatory effects of myeloid cell adenosine receptor A2a stimulation in lipopolysaccharide-induced lung injury. J. Immunol. 2007, 179, 1254-1263. [CrossRef]

163. Montesinos, M.C.; Desai, A.; Delano, D.; Chen, J.F.; Fink, J.S.; Jacobson, M.A.; Cronstein, B.N. Adenosine A2A or A3 receptors are required for inhibition of inflammation by methotrexate and its analog MX-68. Arthritis Rheum. 2003, 48, 240-247. [CrossRef] [PubMed]

164. Montesinos, M.C.; Desai, A.; Chen, J.F.; Yee, H.; Schwarzschild, M.A.; Fink, J.S.; Cronstein, B.N. Adenosine promotes wound healing and mediates angiogenesis in response to tissue injury via occupancy of A(2A) receptors. Am. J. Pathol. 2002, 160, 2009-2018. [CrossRef] 
165. Wang, H.; Zhang, W.; Tang, R.; Zhu, C.; Bucher, C.; Blazar, B.R.; Geng, J.G.; Zhang, C.; Linden, J.; Wu, C.; et al. Adenosine receptor A2A deficiency in leukocytes increases arterial neointima formation in apolipoprotein E-deficient mice. Arterioscler. Thromb. Vasc. Biol. 2010, 30, 915-922. [CrossRef] [PubMed]

166. Sullivan, G.W.; Linden, J.; Buster, B.L.; Scheld, W.M. Neutrophil A2A adenosine receptor inhibits inflammation in a rat model of meningitis: Synergy with the type IV phosphodiesterase inhibitor, rolipram. J. Infect. Dis. 1999, 180, 1550-1560. [CrossRef]

167. Sullivan, G.W.; Rieger, J.M.; Scheld, W.M.; Macdonald, T.L.; Linden, J. Cyclic AMP-dependent inhibition of human neutrophil oxidative activity by substituted 2-propynylcyclohexyl adenosine A(2A) receptor agonists. Br. J. Pharmacol. 2001, 132, 1017-1026. [CrossRef]

168. Steingold, J.M.; Hatfield, S.M. Targeting hypoxia-A2A adenosinergic immunosuppression of antitumor T cells during cancer immunotherapy. Front. Immunol. 2020, 11, 570041. [CrossRef]

169. Burnstock, G. Purinergic signaling in the cardiovascular system. Circ. Res. 2017, 120, 207-228. [CrossRef]

170. Peleli, M.; Fredholm, B.B.; Sobrevia, L.; Carlström, M. Pharmacological targeting of adenosine receptor signaling. Mol. Asp. Med. 2017, 55, 4-8. [CrossRef]

171. Paganelli, F.; Saadjian, A.; Sampol, J.J.; Maixent, J.; Levy, S.; Guieu, R. Effects of percutaneous transluminal coronary angioplasty on coronary adenosine concentrations in humans. Eur. J. Clin. Investig. 2000, 30, 105-110. [CrossRef]

172. Gariboldi, V.; Vairo, D.; Guieu, R.; Marlingue, M.; Ravis, E.; Lagier, D.; Mari, A.; Thery, E.; Collart, F.; Gaudry, M.; et al. Expressions of adenosine A2A receptors in coronary arteries and peripheral blood mononuclear cells are correlated in coronary artery disease patients. Int. J. Cardiol. 2017, 230, 427-431. [CrossRef]

173. Shenoy, V.; Mehendale, V.; Prabhu, K.; Shetty, R.; Rao, P. Correlation of serum homocysteine levels with the severity of coronary artery disease. Indian J. Clin. Biochem. 2014, 29, 339-344. [CrossRef] [PubMed]

174. Headrick, J.P.; Ashton, K.J.; Rose'Meyer, R.B.; Peart, J.N. Cardiovascular adenosine receptors: Expression, actions and interactions. Pharmacol. Ther. 2013, 140, 92-111. [CrossRef]

175. Shryock, J.C.; Belardinelli, L. Adenosine and adenosine receptors in the cardiovascular system: Biochemistry, physiology, and pharmacology. Am. J. Cardiol. 1997, 79, 2-10. [CrossRef]

176. Musser, B.; Morgan, M.E.; Leid, M.; Murray, T.F.; Linden, J.; Vestal, R.E. Species comparison of adenosine and beta-adrenoceptors in mammalian atrial and ventricular myocardium. Eur. J. Pharmacol. 1993, 246, 105-111. [CrossRef]

177. Hussain, T.; Mustafa, S.J. Binding of A1Adenosine receptor ligand [3H]8-cyclopentyl-1,3-dipropylxanthine in coronary smooth muscle. Circ. Res. 1995, 77, 194-198. [CrossRef]

178. Iwamoto, T.; Umemura, S.; Toya, Y.; Uchibori, T.; Kogi, K.; Takagi, N.; Ishii, M. Identification of adenosine A2 receptor-cAMP system in human aortic endothelial cells. Biochem. Biophys. Res. Commun. 1994, 199, 905-910. [CrossRef]

179. Marala, R.B.; Mustafa, J.S. Immunological characterization of adenosine A2A receptors in human and porcine cardiovascular tissues. J. Pharmacol. Exp. Ther. 1998, 286, 1051-1057.

180. Cushing, D.J.; Brown, G.L.; Sabouni, M.H.; Mustafa, S.J. Adenosine receptor-mediated coronary artery relaxation and cyclic nucleotide production. Am. J. Physiol. 1991, 261, H343-H348. [CrossRef]

181. Ledent, C.; Vaugeois, J.M.; Schiffmann, S.N.; Pedrazzini, T.; Yacoubi, M.E.; Vanderhaeghen, J.J.; Costentin, J.; Heath, J.K.; Vassart, G.; Parmentier, M. Aggressiveness, hypoalgesia and high blood pressure in mice lacking the adenosine A2a receptor. Nature 1997, 388, 674-678. [CrossRef] [PubMed]

182. Shryock, J.C.; Snowdy, S.; Baraldi, P.G.; Cacciari, B.; Spalluto, G.; Monopoli, A.; Ongini, E.; Baker, S.P.; Belardinelli, L. A2Aadenosine receptor reserve for coronary vasodilation. Circulation 1998, 98, 711-718. [CrossRef] [PubMed]

183. Berwick, Z.C.; Payne, G.A.; Lynch, B.; Dick, G.M.; Sturek, M.; Tune, J.D. Contribution of adenosine A(2A) and A(2B) receptors to ischemic coronary dilation: Role of K(V) and K(ATP) channels. Microcirculation 2010, 17, 600-607. [CrossRef]

184. Sanjani, M.S.; Teng, B.; Krahn, T.; Tilley, S.; Ledent, C.; Mustafa, S.J. Contributions of A2A and A2B adenosine receptors in coronary flow responses in relation to the KATP channel using A2B and A2A/2B double-knockout mice. Am. J. Physiol. Heart Circ. Physiol. 2011, 301, H2322-H2333. [CrossRef]

185. Monahan, T.S.; Sawmiller, D.R.; Fenton, R.A.; Dobson, J.G. Adenosine A2a-receptor activation increases contractility in isolated perfused hearts. Am. J. Physiol. Heart Circ. Physiol. 2000, 279, H1472-H1481. [CrossRef]

186. Dobson, J. Adenosine A2 receptor function in rat ventricular myocytes. Cardiovasc. Res. 1997, 34, 337-347. [CrossRef]

187. Morrison, R.R.; Talukder, M.A.H.; Ledent, C.; Mustafa, S.J. Cardiac effects of adenosine in A2A receptor knockout hearts: Uncovering A2B receptors. Am. J. Physiol. Heart Circ. Physiol. 2002, 282, H437-H444. [CrossRef] [PubMed]

188. Son, Y.K.; Park, W.S.; Ko, J.H.; Han, J.; Kim, N.; Earm, Y.E. Protein kinase A-dependent activation of inward rectifier potassium channels by adenosine in rabbit coronary smooth muscle cells. Biochem. Biophys. Res. Commun. 2005, 337, 1145-1152. [CrossRef]

189. Zhao, Z.; Francis, C.E.; Ravid, K. An A3-subtype adenosine receptor is highly expressed in rat vascular smooth muscle cells: Its role in attenuating adenosine-induced increase in cAMP. Microvasc. Res. 1997, 54, 243-252. [CrossRef] [PubMed]

190. Zhao, Z.; Makaritsis, K.; Francis, C.E.; Gavras, H.; Ravid, K. A role for the A3 adenosine receptor in determining tissue levels of cAMP and blood pressure: Studies in knock-out mice. Biochim. Biophys. Acta 2000, 1500, 280-290. [CrossRef]

191. Al-Khatib, S.M.; Stevenson, W.G.; Ackerman, M.J.; Bryant, W.J.; Callans, D.J.; Curtis, A.B.; Deal, B.J.; Dickfeld, T.; Field, M.E.; Fonarow, G.C.; et al. 2017 AHA/ACC/HRS guideline for management of patients with ventricular arrhythmias and the prevention of sudden cardiac death: A report of the American college of cardiology/ American heart association task force on clinical practice guidelines and the heart rhythm society. J. Am. Coll. Cardiol. 2018, 72, e91-e220. [CrossRef] 
192. Yellon, D.M.; Hausenloy, D.J. Myocardial reperfusion injury. N. Engl. J. Med. 2007, 357, 1121-1135. [CrossRef]

193. Headrick, J.P.; Lasley, R.D. Adenosine receptors and reperfusion injury of the heart. Handb. Exp. Pharmacol. 2009, 193, 189-214. [CrossRef]

194. Haskó, G.; Cronstein, B.N. Adenosine: An endogenous regulator of innate immunity. Trends Immunol. 2004, 25, 33-39. [CrossRef]

195. Grenz, A.; Homann, D.; Eltzschig, H.K. Extracellular adenosine: A safety signal that dampens hypoxia-induced inflammation during ischemia. Antioxid. Redox Signal. 2011, 15, 2221-2234. [CrossRef] [PubMed]

196. Hart, M.L.; Gorzolla, I.C.; Schittenhelm, J.; Robson, S.C.; Eltzschig, H.K. SP1-dependent induction of CD39 facilitates hepatic ischemic preconditioning. J. Immunol. 2010, 184, 4017-4024. [CrossRef] [PubMed]

197. Grenz, A.; Zhang, H.; Hermes, M.; Eckle, T.; Klingel, K.; Huang, D.Y.; Müller, C.E.; Robson, S.C.; Osswald, H.; Eltzschig, H.K. Contribution of E-NTPDasel (CD39) to renal protection from ischemia-reperfusion injury. FASEB J. 2007, 21, 2863-2873. [CrossRef]

198. Köhler, D.; Eckle, T.; Faigle, M.; Grenz, A.; Mittelbronn, M.; Laucher, S.; Hart, M.L.; Robson, S.C.; Müller, C.E.; Eltzschig, H.K. CD39/ectonucleoside triphosphate diphosphohydrolase 1 provides myocardial protection during cardiac ischemia/reperfusion injury. Circulation 2007, 116, 1784-1794. [CrossRef]

199. Hart, M.L.; Much, C.; Gorzolla, I.C.; Schittenhelm, J.; Kloor, D.; Stahl, G.L.; Eltzschig, H.K. Extracellular adenosine production by ecto-5'-nucleotidase protects during murine hepatic ischemic preconditioning. Gastroenterology 2008, 135, 1739-1750.e3. [CrossRef] [PubMed]

200. Eckle, T.; Krahn, T.; Grenz, A.; Köhler, D.; Mittelbronn, M.; Ledent, C.; Jacobson, M.A.; Osswald, H.; Thompson, L.F.; Unertl, K.; et al. Cardioprotection by ecto-5'-nucleotidase (CD73) and A2B adenosine receptors. Circulation 2007, 115, 1581-1590. [CrossRef] [PubMed]

201. Grenz, A.; Zhang, H.; Eckle, T.; Mittelbronn, M.; Wehrmann, M.; Köhle, C.; Kloor, D.; Thompson, L.F.; Osswald, H.; Eltzschig, H.K. Protective role of ecto-5'-nucleotidase (CD73) in renal ischemia. J. Am. Soc. Nephrol. 2007, 18, 833-845. [CrossRef]

202. Hart, M.L.; Henn, M.; Köhler, D.; Kloor, D.; Mittelbronn, M.; Gorzolla, I.C.; Stahl, G.L.; Eltzschig, H.K. Role of extracellular nucleotide phosphohydrolysis in intestinal ischemia-reperfusion injury. FASEB J. 2008, 22, 2784-2797. [CrossRef]

203. Cronstein, B.N.; Daguma, L.; Nichols, D.; Hutchison, A.J.; Williams, M. The adenosine/neutrophil paradox resolved: Human neutrophils possess both A1 and A2 receptors that promote chemotaxis and inhibit $\mathrm{O} 2$ generation, respectively. J. Clin. Investig. 1990, 85, 1150-1157. [CrossRef] [PubMed]

204. Wallace, K.L.; Linden, J. Adenosine A2A receptors induced on iNKT and NK cells reduce pulmonary inflammation and injury in mice with sickle cell disease. Blood 2010, 116, 5010-5020. [CrossRef]

205. Ohta, A.; Sitkovsky, M. Role of G-protein-coupled adenosine receptors in downregulation of inflammation and protection from tissue damage. Nature 2001, 414, 916-920. [CrossRef]

206. Grenz, A.; Osswald, H.; Eckle, T.; Yang, D.; Zhang, H.; Tran, Z.V.; Klingel, K.; Ravid, K.; Eltzschig, H.K. The reno-vascular A2B adenosine receptor protects the kidney from ischemia. PLoS Med. 2008, 5, e137. [CrossRef]

207. Eckle, T.; Faigle, M.; Grenz, A.; Laucher, S.; Thompson, L.F.; Eltzschig, H.K. A2B adenosine receptor dampens hypoxia-induced vascular leak. Blood 2008, 111, 2024-2035. [CrossRef]

208. Hart, M.L.; Jacobi, B.; Schittenhelm, J.; Henn, M.; Eltzschig, H.K. A2B adenosine receptor signaling provides potent protection during intestinal ischemia/reperfusion injury. J. Immunol. 2009, 182, 3965-3968. [CrossRef]

209. Eckle, T.; Hartmann, K.; Bonney, S.; Reithel, S.; Mittelbronn, M.; Walker, L.A.; Lowes, B.D.; Han, J.; Borchers, C.H.; Buttrick, P.M.; et al. Adora2b-elicited Per2 stabilization promotes a HIF-dependent metabolic switch crucial for myocardial adaptation to ischemia. Nat. Med. 2012, 18, 774-782. [CrossRef]

210. Chhabra, P.; Linden, J.; Lobo, P.; Douglas Okusa, M.; Brayman, K.L. The immunosuppressive role of adenosine A2A receptors in ischemia reperfusion injury and islet transplantation. Curr. Diabetes Rev. 2012, 8, 419-433. [CrossRef]

211. Guieu, R.; Kipson, N.; Ruf, J.; Fournier, N.; Laine, M.; Foucher, M.C.; Fromonot, J.; Mottola, G.; Bruzzese, L.; Boussuges, A.; et al. Low basal expression of A2A adenosine receptors and increase in adenosine plasma concentration are associated with positive exercise stress testing. Int. J. Cardiol. 2015, 180, 15-17. [CrossRef] [PubMed]

212. Varani, K.; Laghi-Pasini, F.; Camurri, A.; Capecchi, P.L.; Maccherini, M.; Diciolla, F.; Ceccatelli, L.; Enea Lazzerini, P.; Ulouglu, C.; Cattabeni, F; et al. Changes of peripheral A 2A adenosine receptors in chronic heart failure and cardiac transplantation. FASEB J. 2002, 17, 280-282. [CrossRef] [PubMed]

213. Gaudry, M.; Marlinge, M.; Deharo, P.; Vairo, D.; Bottone, S.; Mottola, G.; Kipson, N.; Criado, C.; Mace, P.; Chefrour, M.; et al. Pharmacological profile of adenosine A2A receptors in patients with lower extremity peripheral artery disease and associated coronary artery disease: A pilot study. Int. J. Cardiol. 2019, 285, 121-127. [CrossRef]

214. Vairo, D.; Giacobbe, C.; Guiol, C.; Chaptal, M.C.; Di Taranto, M.D.; Bruzzese, L.; Ruf, J.; Guieu, R.; Fortunato, G.; Fenouillet, E.; et al. Correlation between low adenosine A2A receptor expression and hypercholesterolemia: A new component of the cardiovascular risk? Biochim. Biophys. Acta Mol. Cell Biol. Lipids 2021, 1866, 158850. [CrossRef]

215. Bagheri, B.; Zargari, M.; Meshkini, F.; Dinarvand, K.; Mokhberi, V.; Azizi, S.; Rasouli, M. Uric acid and coronary artery disease, two sides of a single coin: A determinant of antioxidant system or a factor in metabolic syndrome. J. Clin. Diagn. Res. 2016, 10, OC27-OC31. [CrossRef]

216. Gaubert, M.; Marlinge, M.; Alessandrini, M.; Laine, M.; Bonello, L.; Fromonot, J.; Cautela, J.; Thuny, F.; Barraud, J.; Mottola, G.; et al. Uric acid levels are associated with endothelial dysfunction and severity of coronary atherosclerosis during a first episode of acute coronary syndrome. Purinergic Signal. 2018, 14, 191-199. [CrossRef] [PubMed] 
217. Bruzzese, L.; Fenouillet, E.; Fromonot, J.; Durand-Gorde, J.M.; Condo, J.; Kipson, N.; Mottola, G.; Deharo, P.; Guieu, R.; Ruf, J. High homocysteine levels prevent via $\mathrm{H} 2 \mathrm{~S}$ the $\mathrm{CoCl} 2$-induced alteration of lymphocyte viability. J. Cell. Mol. Med. 2016, 20, 1411-1419. [CrossRef] [PubMed]

218. Fromonot, J.; Deharo, P.; Bruzzese, L.; Cuisset, T.; Quilici, J.; Bonatti, S.; Fenouillet, E.; Mottola, G.; Ruf, J.; Guieu, R. Adenosine plasma level correlates with homocysteine and uric acid concentrations in patients with coronary artery disease. Can. J. Physiol. Pharmacol. 2016, 94, 272-277. [CrossRef] [PubMed]

219. Deharo, P.; Marlinge, M.; Guiol, C.; Vairo, D.; Fromonot, J.; Mace, P.; Chefrour, M.; Gastaldi, M.; Bruzzese, L.; Gaubert, M.; et al. Homocysteine concentration and adenosine $\mathrm{A}(2 \mathrm{~A})$ receptor production by peripheral blood mononuclear cells in coronary artery disease patients. J. Cell. Mol. Med. 2020, 24, 8942-8949. [CrossRef] [PubMed]

220. Ruf, J.; Vairo, D.; Paganelli, F.; Guieu, R. Extracellular vesicles with ubiquitinated adenosine A(2A) receptor in plasma of patients with coronary artery disease. J. Cell. Mol. Med. 2019, 23, 6805-6811. [CrossRef] [PubMed]

221. Koupenova, M.; Ravid, K. Biology of platelet purinergic receptors and implications for platelet heterogeneity. Front. Pharmacol. 2018, 9, 37. [CrossRef] 